\title{
(In)Seguranças e terrorismos: um estudo comparado entre as mídias online BBC e a Dabiq Magazine a partir dos ataques em Paris
}

(In)Security and terrorism: a comparative study between the online media BBC and Dabiq Magazine from the attacks in Paris

(In)Seguridad y terrorismo: un estudio comparado entre los medios online BBC y la Dabiq Magazine a partir de los ataques en París

DOI: 10.1590/1809-5844201925

\section{Pablo Victor Fontes Santos ${ }^{1}$}

https://orcid.org/0000-0001-5138-6773

Monica Herz ${ }^{1}$

https://orcid.org/0000-0003-2061-2699

\section{Jéssika Cardoso de Medeiros ${ }^{2}$}

https://orcid.org/0000-0001-9242-3171

${ }_{1}^{1}$ (Pontifícia Universidade Católica do Rio de Janeiro, Instituto de Relações Internacionais, Programa de PósGraduação em Relações Internacionais. Rio de Janeiro - RJ, Brasil).

${ }^{2}$ (Universidade Federal Fluminense, Instituto de Arte e Comunicação Social, Programa de Pós-Graduação em Comunicação. Rio de Janeiro - RJ, Brasil).

\section{Resumo}

A partir de uma perspectiva comparada e de uma reflexão de cunho foucaultiano, este $\operatorname{artigo~}^{1}$ tem como propósito analisar as construções discursivas sobre (in)segurança internacional, produzidas pelas reportagens jornalísticas da British Broadcasting Corporation (BBC) e pela Dabiq Magazine, de modo a desestabiliza-las. Ressalta-se que o fato histórico investigado corresponde aos ataques em Paris de 13 de novembro de 2015, tendo em vista a audiência midiática então produzida. Assim, o artigo busca refletir sobre a seguinte pergunta: como a BBC e a Dabiq Magazine construíram seus discursos sobre a (in)segurança internacional a partir da temática do terrorismo? Em face desse questionamento, temos como reflexão que as construções discursivas das mídias online ocorrem

1 Agradecemos as constribuições a partir dos comentários feitos pelos acadêmicos Marcial Alecio Garcia Suarez (DCP/UFF), Graciela de Conti Pagliari (PPGRI/UFSC) Mônica Lessa (PPGRI/UERJ), Cristina Rego Monteiro da Luz (ECO/UFRJ), Yesa Portela (IRI/PUC-RIO) e Renee Couto (PPGRI/UERJ) e os pareceristas da revista Intercom. 
segundo duas questões. De um lado, existe a transmissão de ideias e valores mediante a lógica de "segurança”, "solidariedade” e retorno à “normalidade”; por sua vez, a partir de outro espectro, há a construção da sensação de insegurança, de tragédias e de desespero. Nesse sentido, de modo a empreender este estudo, metodologicamente foram utilizadas referências bibliográficas acerca do tema sobre os estudos críticos de (in)segurança internacional, terrorismos, análises de discurso. Desse modo, foi realizado um estudo pormenorizado que comparou as capas das mídias online, uma vez que ambas são calcadas em seus respectivos regimes de verdade, poder e conhecimento.

Palavras-chave: CSS. Terrorismos. Estado Islâmico. Dabiq. BBC.

\begin{abstract}
From a comparative perspective and a Foucauldian reflection, this article aims to analyze the discursive constructions about international (in)security, produced by the British Broadcasting Corporation (BBC) and Dabiq Magazine journalistic reports, in a way that it destabilizes itself. It is worth noting that the historical fact investigated corresponds to the November 13, 2015 attacks in Paris, in view of the media audience then produced. Thus, the article seeks to reflect on the following question: how did the BBC and Dabiq Magazine construct their discourses on international (in) security on the subject of terrorism? In face of this questioning, we have, as a reflection, that the discursive constructions of the online media occur according to two questions. On one hand, there is the transmission of ideas and values through the logic of "security", "solidarity" and return to "normality"; In turn, from another spectrum, there is the construction of a sense of insecurity, tragedy and despair. In this sense, in order to undertake this study, methodologically were used bibliographical references on the topic of critical studies of international (in)security, terrorisms, discourse analysis. Thus, a detailed study was conducted comparing the layers of the online media, since both are based on their respective regimes of truth, power and knowledge.
\end{abstract}

Key-words: CSS. Terrorism. IE. Dabiq. BBC.

\title{
Resumen
}

A partir de una perspectiva comparada y de una reflexión de cuño foucaultiano, este artículo tiene como propósito analizar las construcciones discursivas sobre (in)seguridad internacional, producidas por los reportajes periodísticos de la British Broadcasting Corporation (BBC) y la Dabiq Magazine, para desestabilizar-las. Se resalta que el hecho histórico investigado corresponde a los ataques en París del 13 de noviembre de 2015, teniendo en vista la audiencia mediática entonces producida. Así, el artículo busca reflexionar sobre la siguiente pregunta: ¿cómo la BBC y la Dabiq Magazine construyeron sus discursos sobre la (in)seguridad internacional a partir de la temática del terrorismo ?. En vista de este cuestionamiento, tenemos como reflexión que las construcciones discursivas de los medios online ocurren según dos cuestiones. De un lado, existe la transmisión de ideas y valores mediante la lógica de "seguridad”, "solidaridad” y retorno a la "normalidad”; a su vez, a partir de otro espectro, hay la construcción de la sensación de inseguridad, de tragedias y de desesperación. En este sentido, y de modo a emprender este estudio, metodológicamente se utilizaron referencias bibliográficas acerca del tema sobre los estudios críticos de (in)seguridad 
internacional, terrorismo, análisis de discurso. De este modo, se realizó un estudio detallado que comparó las capas de los medios online, ya que ambas se calcaban en sus respectivos regímenes de verdad, poder y conocimiento.

Palabra clave: CSS. Terrorismo. Estado islámico. Dabiq. BBC.

\section{Introdução}

Desde sua origem, no início dos anos 2000, o grupo intitulado Estado Islâmico (EI) moldou e alterou suas estruturas até chegar ao que se conhece atualmente. Diferentemente de muitos outros grupos associados às práticas/ações terroristas, o EI ganhou notoriedade não apenas por difundir o terrorismo ${ }^{2}$, mas porque se utilizou e se utiliza dos meios de comunicação digital e das redes sociais para disseminar seus valores, suas ideias e suas respectivas concepções sobre o mundo. Ademais, cabe apontar que, após o ano de 2014, com a declaração do Califado, a atuação do grupo se tornou mais ostensiva, com constantes atividades de combatentes no Oriente Médio e com a expansão geopolítica pelo globo.

No transcorrer do tempo, as atividades midiáticas do grupo (EI) também tomaram forma e força. A Dabiq ${ }^{3}$, revista online, tornou-se uma das principais ferramentas de marketing utilizadas pelo grupo. Porém, é preciso apontar que, para além da Dabiq Magazine, o grupo possui uma extensa cadeia de operação midiática ${ }^{4}$. Cadeia essa que opera por meio de diversas plataformas, como publicações online, aplicativos para celular, redes sociais e vídeos, por meio dos quais o grupo exalta os feitos militares e as crenças religiosas para fins propagandísticos.

Os objetivos externos do EI compreendem uma zona de influência direta, voltada para o continente europeu, que abrange, por exemplo, a França - país que, no dia 13 de novembro de 2015, foi alvo de diversos ataques em sua capital, Paris. Ressalta-se que tal evento teve forte repercussão na mídia internacional, ganhando também espaço no periódico do grupo terrorista. Dessa maneira, os ataques de Paris, em novembro de 2015, foram utilizados como marco temporal para delimitar o escopo de pesquisa. Além disso, optou-se por realizar, neste artigo, duas análises de discurso comparativas entre a Dabiq Magazine e a BBC ${ }^{5}$ (uma das maiores corporações midiáticas da Europa).

\footnotetext{
2 Não se pretende, neste artigo, problematizar os diversos conceitos e suas respectivas ampliações sobre a questão do terrorismo internacional. Busca-se, apenas, apontar de que modo as diversas práticas e ações realizadas pelas mídias (BBC e Dabiq Magazine) são construídas a partir de suas narrativas discursivas jornalisticamente sobre a (in)segurança, especificamente na temática sobre o terrorismo.

3 A Dabiq Magazine é a versão em inglês da publicação. Também há produção de periódicos em outros idiomas, como o turco, francês e russo. Optou-se pela publicação em inglês neste trabalho.

4 Dentro dessa divisão midiática, encontra-se uma estação de rádio (Al-Bayan), que é transmitida na Síria, Iraque e Líbia, mas possui alguns boletins diários que são noticiados em outras línguas, como inglês, francês, russo e turco. Também detém uma agência de notícias Amaq, que reporta as ações do grupo dentro e fora do território do Oriente Médio e uma divisão de mídia em língua estrangeira (Al-Hayat Media Center), responsável pelas revistas, produção dos vídeos e por outros aplicativos para celular.

5 A escolha pela BBC deve-se, por um lado, à audiência global que, no ano de 2017, registrou, em média, cerca de 372 milhões de pessoas. Além disso, a escolha pela BBC pautou-se pelo alcance que a emissora tem em quase todos os países. Optou-se, desse modo, pela BBC diante da possibilidade de termos uma visão mais europeia e não somente uma perspectiva francesa. Disponível em: https:// www.bbc.co.uk/aboutthebbc/insidethebbc/howwework/reports/ara/archive\#heading-201516. Acesso em: 1 fev. 2019.
} 
Cabe apontar que, em ambos os objetos de pesquisa estudados, há uma dificuldade quanto à análise discursiva, tendo em vista que ambas as mídias detêm suas especificidades amparadas em seus respectivos regimes de conhecimento, poder, verdade e caracterizadas por hierarquias. Isto posto, o artigo busca refletir sobre a seguinte pergunta: como a BBC e a Dabiq Magazine construíram seus discursos sobre a (in)segurança internacional a partir da temática do terrorismo? Em face desse questionamento, temos como reflexão que as construções discursivas e as narrativas ocorrem segundo duas questões. De um lado, existe a transmissão de ideias e valores mediante a lógica de "segurança”, "solidariedade” e a retorno à "normalidade”; e, por outro espectro, há a construção da sensação de insegurança, de tragédias e de desespero. Considera-se que ambas as reflexões não são excludentes, mas, sim, complementares.

No que concerne às divisões do artigo, realizou-se, primeiramente, uma reflexão sobre a importância da contribuição dos Estudos Críticos de (In)Segurança Internacional e dos Estudos Críticos de Terrorismo a partir dos atores não estatais, sobretudo o impacto do Estado Islâmico por intermédio das/nas mídias. Em um segundo momento, o texto versa sobre a importância teórica/metodológica da análise do discurso foucaultiana pós-estruturalista. Por fim, na última seção, o artigo faz uso de modo pormenorizado da análise de discurso em perspectiva comparada, tendo como estudos de caso a Dabiq Magazine e a BBC. Dessa maneira, é realizada uma intersecção entre os estudos de (in)segurança internacional, terrorismos e mídias de modo interdisciplinar.

\section{Estudos Críticos de (In)Segurança Internacional e os Estudos Críticos de Terrorismos (CTS): pós-estruturalismos, Estado Islâmico e mídias}

Até o fim da década de 1980, os estudos realistas e suas ramificações tinham o Estado como o único e principal ator das Relações Internacionais. Considerava-se, portanto, que este era o único elemento que deveria tão somente ser estudado. Ancorados por métodos positivistas e caracterizados por análises pautadas pela objetividade, pela imparcialidade e pela neutralidade, os realismos predominaram nas análises do campo da segurança internacional, sob a égide do behavorismo ${ }^{6}$. Ainda assim, é possível apontar que esta corrente teórica e suas ramificações entendiam (e entendem) que somente o Estado é quem produz (in) segurança. Não havia (e não há), portanto, espaço para debates fora da caixa estadocêntrica (BOOTH, 2007).

Porém, é importante destacar que, após o fim da Guerra Fria (1991), os estudos sobre (in)segurança internacional ${ }^{7}$ passaram por mudanças e inovações. Isso porque, após diversas pressões, e diante de conflitos, emergiram questionamentos acerca da capacidade de os

6 Cabe uma ressalva nesta análise sobre os realismos, tendo em vista que, após algumas décadas, um grupo de autores intitulados realistas neoclássicos passou a se distanciar das perspectivas behavoristas, retomando, portanto, as perspectivas do realismo clássico de Edward Carr, Hans Morgenthau e Raymond Aron.

7 O conceito de dessecuritização busca, por meio da despolitização, fazer com que as agendas/temas/processos da (in) segurança internacional que em outrora tinham relevância, percam espaço na pauta política (BUZAN; WEAVER; WILDE, 1998). 
Estados solucioná-los. Assim, a partir das inflexões na Arquitetura do Sistema Internacional, e com a chegada de novas perspectivas teóricas, os estudos de (in)segurança ganharam novas contribuições teóricas/metodológicas que revolucionaram o campo, constituindo os Estudos Críticos de Segurança (CSS).

Autores como Buzan, Weaver e Wilde (1998), ao lançarem obras a partir da temática sobre a (in)segurança, sob uma visão pós-positivista, apontaram que a subjetividade, a não neutralidade e a parcialidade passaram não apenas a ampliar, mas também a relativizar os atores e as agendas que antes eram marginalizados pelas perspectivas tradicionais das escolas realistas e seus derivados ${ }^{8}$. A Escola de Copenhagen, à qual pertencem estes autores, ao abordar o conceito de securitização ${ }^{9}$ e dessecuritização ${ }^{10}$, passou a politizar temas/agendas/ processos vinculados ao Estado e também aqueles deslocados da agenda estatal (BUZAN; HANSEN, 2009).

A partir de Copenhagen e diante da possibilidade de ampliação de novos temas e agendas da (in)segurança internacional, sugiram novas escolas ${ }^{11}$, como Paris ${ }^{12}$ (com Didier Bigo $^{13}$ e Jef Huysmans ${ }^{14}$, em 1990) e Aberystwyth ${ }^{15}$ (com Ken Booth e Wyn Jonnes, em 1991). Essas escolas trouxeram novas metodologias, epistemologias e ontologias sobre os estudos voltados ao internacional (BIGO; TSOUKALA, 2008; HUYSMANS; SQUIRE, 2009; KRAUSE; WILLIAMS, 1997; WEAVER, 2004; NEOCLEOUS, 2008).

Feita esta breve digressão acerca do contexto das escolas críticas na área de (in) segurança internacional e da apresentação de suas respectivas teorias/visões, cabe apontar

8 Assim, temas e agendas como a segurança humana, ambiental, energética e os estudos sobre terrorismos e o terror ganharam espaço e, com o transcorrer do tempo, tornaram-se subcampo nas Relações Internacionais (BUZAN; HANSEN, 2009).

9 Compreende-se o conceito de securitização como uma forma de politização de um tema/agenda/processo da agenda de (in) segurança internacional que geralmente é compreendida como uma ameaça/risco/medo. Em teoria, qualquer emissão pública/ discurso/questão pode ser localizada pelos atores estatais e não estatais de modo que a politização aconteça (BUZAN; WEAVER; WILDE, 1998).

$10 \mathrm{O}$ conceito de dessecuritização busca, por meio da despolitização, fazer com que as agendas/temas/processos da (in)segurança internacional que, em outrora, tinham relevância, percam espaço na pauta política (BUZAN; WEAVER; WILDE, 1998).

11 Cabe uma ressalva neste artigo: todas as escolas supracitadas dos (CSS) detêm diversas influências teóricas que vão desde os construtivismos, feminismos, pós-estruturalismos e mesmo os estudos sobre gêneros aplicados à área de (in)segurança internacional. Dito isto, muitos teóricos entendem que não há teorias de (in)segurança internacional, mas, sim, teorias das Relações Internacionais que são aplicadas ao campo da (in)segurança internacional (BOOTH, 2007; BUZAN; HANSEN, 2009).

12 Historicamente, Paris tem sido o principal local do desenvolvimento teórico inspirado, em especial, por sociólogos como Pierre Bourdieu e filósofos como Michael Foucault, cujo objetivo é produzir investigações empíricas pormenorizadas por meio das práticas que são realizadas por diversas agências/organizações internacionais, regionais e lociais,segundo os diferentes padrões e processos sobre a (in)segurança internacional (BOOTH, 2007; WEAVER, 2004).

13 Didier Bigo é a principal figura da Escola de Paris, principalmente porque desenvolveu o jornal Cultures \& Conflits, no qual foi publicada uma série de trabalhos importantes envolvendo a fusão entre a segurança interna e a segurança externa. Seus trabalhos abordam a intersecção entre a polícia, militares e as agentes de fronteiras e suas respectivas organizações que exercem controle, vigilância e monitoramento.

14 Jef Huysmans, expoente da Escola de Paris, produziu, conjuntamente a outros autores do journal, uma nova imagem sobre a ideia de ameaça, conectando constantemente a imigração, o crime organizado e os terrorismos (WEAVER, 2004; BIGO; TSOUKALA, 2008; HUYSMANS; SQUIRE, 2009).

15 Já Aberystwyth é uma escola que teve um movimento amplo, emergindo de muitas fontes, dentro e fora da Europa. As duas figuras principais dos Estudos Críticos de Segurança de Aberystwyth são Ken Booth e Richard Wyn Jones. No âmbito histórico, um dos principais trabalhos produzidos por esta escola deu-se por meio da edição realizada por Keith Krause (Genebra) e Mike Williams (então Portland, Maine). De modo geral, autores pertencentes a Aberystwyth constatemente fazem uso do conceito de emancipação, tendo em vista, principalmente, o diálogo construído com os autores e remanecentes da Escola de Frankfurt, como Adorno, Horkheimer e Walter Benjamin (KRAUSE; WILLIAMS, 1997; WEAVER, 2004; NEOCLEOUS, 2008). 
que, sob a influência da globalização e a partir dos impactos da tecnologia da comunicação e da informação, o terrorismo passou a ser cada vez mais estudado e problematizado na agenda de (in)segurança. Assim, na próxima seção, aponta-se que, em um cenário também caracterizado pelas chamadas Novas Guerras ${ }^{16}$, uma infinidade de novas análises pode ser apresentada, vinculada e não associada necessariamente à dimensão estatal, principalmente o terrorismo por meio de suas práticas e teorias (PISOIU; HAIN, 2018).

Anterior aos Estudos Críticos de Segurança, desde o período da Guerra Fria, entre 1970-1980, diversos estudos sobre o terrorismo foram realizados segundo as visões ortodoxas lideradas pelo Ocidente. Desde 1980, mas, principalmente, após os atentados de 11 de setembro de 2001, diversos(as) teóricos(as) passaram a questionar os estudos dos terrorismos ortodoxos, com o objetivo de abordar - a partir de diferentes ontologias, epistemologias, métodos - análises que permitissem reflexões à luz de teorias pós-positivistas sobre o tema. No âmbito da British International Studies Association (BISA), no Reino Unido, na renomada Escola de Gales, um grupo de estudiosos construiu uma espécie de Área Temática (AT) intitulada os Estudos Críticos de Terrorismo (CTS), que passou a produzir trabalhos acadêmicos sobre os terrorismos fazendo uso de múltiplas abordagens, principalmente aquelas com foco na crítica imanente segundo o conceito de emancipação (JACKSON, 2009a; McDONALD, 2007; STUMP; DIXIT, 2013).

Tanto no CTS quanto no CSS, as reflexões sobre os terrorismos se utilizaram, dentre as diversas questões, dos estudos sobre linguagem, discursos e estéticas, de acordo com as análises pós-estruturalistas e, especificamente, segundo as reflexões foucaultianas uma espécie de "Escola de Copenhagen” dos estudos críticos de terrorismos (JACKSON; SMYTH; GUNNING, 2009; STUMP; DIXIT, 2013). A partir desta pequena digressão, observamos que, de um modo geral, há certa busca de muitos teóricos tanto da Escola de Gales, de autonomização dos estudos do CTS vis-à-vis ao CSS.

Historicamente e, principalmente, após os atentados de 11 de setembro de 2001, múltiplos discursos projetados por Chefes de Estado e por meios de comunicação passaram a impactar a agenda global da (in)segurança internacional, tendo em vista as imagens espetacularizadas a partir da massiva construção imagética sobre o terrorismo e, a posteriori, o discurso anti-terrorismo. Foi diante dos (e após os) eventos do 11 de setembro de 2001 que passamos a compreender o conceito de terrorismo como um discurso, cuja linguagem produz diversas formas de violência de modo rotineiro (JACKSON, 2004, 2009a).

Sob o viés discursivo, as ações terroristas, mas não somente, passaram a ser estimuladas, principalmente, quando faziam uso da comunicação e linguagem. Assim, compreende-se que as ações discursivas dos atores políticos que difundem o terror são construídas a partir de seus regimes de verdade, conhecimento e poder. Nessas ações midiáticas, os atores buscam exercer influência (poder), a partir de práticas capilarizadas,

16 Ver em Kaldor (2016). 
sobre os múltiplos públicos, utilizando diversos meios de comunicação e suas respectivas técnicas discursivas.

Nesse cenário, um dos personagens que se tornou cada vez mais presente nas principais capas de revistas e jornais do mundo, a partir dos discursos e dos Speech Acts ${ }^{17}$ sobre a agenda de (in)segurança internacional, foi o Estado Islâmico (cujo discurso religioso está baseado no wahabismo, subconjunto do salafismo jihadista). Ressalta-se que, no que concerne ao salafismo jihadista, cabe uma pequena digressão. Atualmente existem duas correntes de ideias que contribuíram para a eclosão do pensamento jihadista. A primeira está associada com a Irmandade Muçulmana, grupo fundado em 1928, no Egito, e que compreendia que o califado deveria ser o sistema de governo para o mundo islâmico a partir de uma reforma do Islã, visando à restauração da pureza doutrinária. A segunda é o salafismo, de origem sunita, que prega a pureza doutrinária da religião islâmica. Nessa vertente, existe a busca por eliminar a idolatria da religião e afirmar a unicidade de Deus (tawhid) (BUNZEL, 2015; COCKBURN, 2015; NAPOLEONI, 2015).

Por sua vez, dentro do salafismo existe o wahabismo, movimento religioso que exerce influência direta no Estado Islâmico e que consiste no retorno às origens do Islã, com o desprezo e a hostilidade aos muçulmanos que não possuem a mesma visão ideológica. Desse modo, o salafismo jihadista surgiu pela combinação dessas correntes e, em um momento posterior, chegou ao Estado Islâmico por Abu Musab al-Zarqawi, jordaniano que, na década de 1980, foi para o Afeganistão lutar ao lado dos mujahedin contra o Exército soviético (BUNZEL, 2015; COCKBURN, 2015; NAPOLEONI, 2015).

Em 2001, quando os Estados Unidos invadiram o Afeganistão, Zarqawi ${ }^{18}$ (líder) e seus seguidores se viram obrigados a se mudar para áreas no território iraquiano, onde, em 2002, foi constituído o grupo Jama’at al-Tawhid wa’al-Jihad (Organização do Monoteísmo ou Unidade e Jihad). Todavia, somente em 2004, Zarqawi jurou lealdade à Al-Qaeda e rebatizou seu grupo como Al-Qaeda no Iraque (AQI). No ano de 2006, foi formado o Mujahidin Shura Council, que buscava unir a AQI e os outros grupos jihadistas que também atuavam na região. Esse foi o primeiro passo do desejo nutrido pelo líder da AQI de formar um califado. Após a morte de Zarqawi (causada por um ataque aéreo norte-americano), Abu Umar al-Baghdadi foi nomeado líder, renomeando o grupo como Estado Islâmico do Iraque (EII) (BUNZEL, 2015; NAPOLEONI, 2015).

Buscando cooptar indivíduos que se identificassem com as causas e os objetivos do grupo terrorista, o EI passou a investir nos meios de comunicação ("tradicionais” e digitais), tendo em vista o impacto e o poder de mobilização junto à opinião pública internacional. A

17 Entende-se o conceito de Speech Act como certas afirmações por meio de discursos que são descritos a partir de uma determinada realidade e que não podem ser julgados como falsas ou verdadeiras. Os Speech Acts são ações estratégicas do discurso no qual existe o uso da persuasão, podendo ser de cunho filosófico ou sociológico. Cabe ponderar que os Speech Acts podem silenciar, marginalizar e, portanto, excluir, tendo em vista as regras/normas que estão calcados (BALZACQ, 2011; VULTEE, 2011; LEONARD; KAUNERT, 2011).

18 O primeiro contato com a Al-Qaeda e seu líder, Osama Bin Laden, ocorreu no ano de 2000. No entanto, em um primeiro momento, Zarqawi tinha outras prioridades, e se recusou a fazer parte da Al-Qaeda (BUNZEL, 2015). 
forma encontrada pelo EI se deu pela divulgação de conteúdos jornalísticos e de vídeos em uma comunicação em rede. Além disso, o marketing produzido pelo EI tem como ênfase a desestabilização e mesmo a desconstrução dos discursos (reportagens e matérias) das mídias ocidentais, com elevada circulação de conteúdo jornalístico, que apenas apontam para uma visão unidirecional sobre o terrorismo, "esquecendo" o passado e a dívida histórica durante e mesmo após o fim da "colonização".

Como bem lembra Huysmans (2006), as (in)seguranças são fenômenos construídos politicamente e socialmente. Nos meios de comunicação, tanto nos mainstream como, por vezes, nos alternativos, os discursos sobre as (in)seguranças são enfatizados e reafirmados por meio da linguagem, da estética (fotografias), do framing ${ }^{19}$ e de tantos outros recursos. Os jogos de linguagem amparados na estética da TV e no meio impresso criam e constroem um imaginário a partir das representações por meio das quais imagens como a anarquia, o caos e a barbárie são evocados. Há um marketing do terror, principalmente, quando, por meio das redes sociais, os discursos anti- terrorismo enquadram o inimigo - nesse caso, os terroristas como aqueles que estão em uma guerra global contra o Ocidente. As afirmações discursivas dos Chefes de Estado, difundidas pelas mídias, atestam que é preciso colocar um fim ao eixo do mal, como apontou o ex-presidente estadunidense George W. Bush (20012009) (SHAPIRO, 2009; REINHARDT, 2018).

É nesse sentido que destacamos que há uma necessidade, cada vez maior, em refletir sobre a importância dos estudos entre (in)seguranças, terrorismos e mídias, principalmente por meio das produções discursivas produzidas pelos diversos atores estatais e não estatais da política mundial. O modo subliminar em que as mensagens são transmitidas pelos meios de comunicação (inclusive no âmbito virtual), tanto pela BBC quanto pela Dabiq Magazine (EI), são calcadas na natureza dos discursos político sobre o terror e o terrorismo como uma tática para atingir seus principais objetivos elencados, principalmente, após 2001, quando o terrorismo atingiu 31 mil incidentes terroristas com aproximadamente 64 mil mortes, de acordo com a base de dados do Terrorismo Global (GTD) (STEPANOVA, 2014; STAMPNITZKY, 2013).

No CSS, e também no CTS, alguns acadêmicos como Hansen (2011) estudam e refletem sobre mídia, (in)segurança e terrorismo segundo o conceito de visual securitization. Hansen (2011) compreende por visual securitization, as ambiguidades que as imagens produzem sobre as (in)seguranças. Assim, por intermédio dos gêneros visuais (ironia, sátira etc), diversas representações imagéticas podem ser geradas. Uma das formas de securitização visual se dá pelo discurso tradicional da segurança, no qual o Outro (neste caso o EI) é estigmatizado como demônio, bárbaro, maligno e ameaçador. Outra maneira de abordar a securitização visual, segundo Hansen (2011) pode ser vista a partir das estratégias calcadas no desprezo pelo outro, utilizando, por exemplo, adjetivos como fraco e pequeno. Uma terceira maneira de representação é a familiaridade com a qual a securitização pode ser feita,

19 Ver o conceito em Goffmann (2016). 
isto é, considerando algo como divino, sagrado. A quarta forma de representação pode ser visualizada por intermédio do sofrimento. Nesse caso, as imagens abordam as concepções do oprimido, ameaçado, morrendo de fome etc.

Como observado, as imagens e suas implicações políticas produzem múltiplos impactos e diversas formas de violências por meio dos seus gêneros textuais, segundo as linguagens verbais e não verbais presentes nos discursos (HANSEN, 2011). A partir dessas perspectivas cabem alguns questionamentos: 1) Quem intitula um indivíduo, Estado e/ou grupo como terrorista? 2) Por que países que exercem violência tanto quanto as práticas/ações de grupos terroristas não são chamados de terroristas? 3) E as mídias, como e de que modo operam como reprodutores de estereótipos sobre aqueles enquadrados como terroristas? 4) Como as capas dos meios de comunicação heterogêneos constroem o imaginário sobre o terror e o terrorismo? 5) Como são calcados os regimes de conhecimento, poder e verdade da BBC e da Dabiq Magazine? 6) De que modo a Dabiq Magazine encontrou nas mídias tradicionais e digitais formas de produção de poder, conhecimento e verdade? 7) Como a Dabiq Magazine se diferencia dos conteúdos jornalísticos produzidos pela BBC?

\section{Pós-Estruturalismo, Análise de Discurso Foucaultiana: mídia, (in) seguranças e terrorismos}

Observa-se, a partir das últimas décadas do século $\mathrm{XX}$, um vertiginoso desenvolvimento tecnológico dos meios de comunicação, marcado pelo surgimento de novas mídias, como a Internet, o celular e o IPTV, e, por conseguinte, pela transformação do status e do consumo da informação. Novas estratégias, inclusive na área de segurança privada, passaram a ser organizadas para a sobrevivência do ameaçado controle do establishment sobre a informação, assim como para a sobrevivência das tradicionais imprensas escrita e televisiva, que passaram a concorrer com uma infinidade de blogs, sites, redes de sociabilidades e IPTVs. Esses novos recursos midiáticos reconfiguraram a produção e o consumo da informação de modo transnacional e transgovernamental ${ }^{20}$ (SLAUGHTER; HALE, 2010).

De um modo geral, as reflexões nas Relações Internacionais sobre mídias, (in) seguranças e terrorismos analisadas de modo interdisciplinar no CTS e no CSS, a partir da colaboração de áreas como a Sociologia, Antropologia, Filosofia e os Estudos Culturais, buscam problematizar como as linguagens, narrativas, discursos, estéticas, semiologias visualizadas nos meios de comunicação (digitais e tradicionais), Estados e Instituições Internacionais. Por meio de múltiplos atores da política mundial há a produção de múltiplas formas de violência (normalizadas, normatizadas e as exceções) por meio das representações, mas não somente, e, ao mesmo tempo, existe uma variedade de produções acadêmicas que

20 As redes transgovernamentais são instituições informais que ligam reguladores, legisladores e outros atores além das fronteiras como forma de operacionalizar a governança global (SLAUGHTER; HALE, 2010). 
abordam os estudos sobre identidade/diferença (OLIVERIO, 1998; ALTHEIDE, 2006; DEBRIX, 2008; HODGES, 2011). No entanto, cabe ponderar quais as diferenças teóricas e metodológicas que o CSS e o CTS, por meio dos teóricos(as), possuem ao evocarem a temática das mídias, seguranças e terrorismos de modo interdisciplinar.

Em um mundo globalizado ${ }^{21}$, a Revista Dabiq Magazine, vinculada ao Estado Islâmico (EI), é um exemplo desse movimento de transformação e questionamento da ordem internacional. Sua publicação ocorre de modo online, bimestralmente e é por meio dela que a organização do EI produz seus discursos, segundo seus regimes de verdade, conhecimento e poder, por meio de diversas técnicas de propaganda e marketing nas reportagens produzidas. Por sua vez, a British Broadcasting Corporation (BBC) é outro meio de comunicação que ganhou relevância nos últimos anos por conta das ampliações e inovações que alcançou, sendo vista e comparada à estrutura de uma agência de notícias internacional como a Reuters e France Press. Além disso, a BBC pertence a uma das regiões do mundo que vem sofrendo com os atentados a partir das ações terroristas pelos membros que compõem o EI. Nesse sentido, a escolha por estes dois objetos é essencial para entendermos como ambas as mídias, nos seus variados tipos e estilos, por vezes hierarquizam, silenciam e produzem regimes de conhecimento, poder e verdade a partir dos seus respectivos enquadramentos e composições estéticas no âmbito da semiologia.

Hansen (2011) aponta para a importância entre os estudos sobre as imagens e os estudos sobre (in)segurança, principalmente em um mundo onde as imagens podem ser difundidas e transmitidas com uma ampla circulação e, ao mesmo tempo, com uma interpretação ambígua. Há cada vez mais estratégias de representação simbólicas que podem ser construídas por intermédio do uso da imagem. Segundo Hansen (2011), de um modo geral, os discursos verbais e não verbais que as imagens (re)produzem podem construir e legitimar a sensação de perigo e de ameaça.

Assim, estudar a securitização visual exige, por um lado, a observação da maneira como os discursos são construídos e constituídos sobre o espectro da (in)segurança e, por outro, dar ênfase à questão do poder simbólico que as imagens podem produzir a partir de sua independência, inclusive de modo ambíguo (HANSEN, 2011). Por intermédio da linguagem discursiva, os objetos, os assuntos e as estruturas ganham relevância, dados os significados e o impacto que produzem na sociedade para além da representação linguística. Nesse sentido, os discursos, por meio de suas linguagens, são usados para reforçar certas visões de mundo ancoradas nos imaginários (re)produzidos pelos atores da política mundial. No âmbito do CTS e no CSS, as reflexões pós-estruturais foucaultianas cada vez mais ganham espaço e legitimidade, principalmente quando linguagens, discurso, são compreendidas como formas de produção de verdades, conhecimento e poder junto à comunidade internacional (JACKSON, 2009a, 2009b).

21 Compartilhamos a visão de Held e McGrew (2002) sobre a definição de globalização. 
Em termos epistemológicos, as grandes narrativas discursivas servem como um modo de autofundação, enquanto que, no nível político, servem como autorregulamentação ou autoafirmação. Ao olharmos para a lógica Ocidental, é possível realizar uma desestabilização dos discursos que legitimam a dominação as implicações políticas e morais (DEVETAK, 2007). Como um livro, o discurso não apresenta de modo nítido e nem de forma determinada as suas essências; na realidade, desde suas primeiras linhas até o ponto final, exibem unidades que são relativas e variáveis. Portanto, os discursos não podem ser considerados unidades imediatas e homogêneas (FOUCAULT, 1997).

Segundo Foucault (1997), ao olharmos para os meios de comunicação e seus modos de atuação na política mundial, podemos observar as críticas que algumas mídias realizam às “regras discursivas universais” já pré-estabelecidas. Mas, ao mesmo tempo, é possível observar que as mesmas mídias podem promover o silenciamento de temas e de vozes ao empregar "novos" e resgatar antigos discursos (FOUCAULT, 1997). As mídias, por vezes, incitam a violência a partir de múltiplas formas, inclusive por meio de estereótipos e produção de hierarquias mediante os discursos e suas linguagens, sobretudo nas capas de seus periódicos tradicional e digital.

As capas são calcadas em diversos elementos semiológicos como signo, significado, significante, canal, meio, mensagem e, portanto, produzem formas de estabelecer, com os diversos públicos, modos de produção da informação e não necessariamente comunicação e vive-versa. No campo da (in)segurança, compreendemos as imagens, representadas nas capas online da BBC e da Dabiq Magazine, como um produto do discurso oriundo das práticas sociais e políticas (SALTER; MUTLU, 2013; STUMP; DIXIT, 2013; ARADAU et al, 2015). Cabe ressaltar que, por meio dos discursos, observamos a existência de elementos de dominação, de construções de hierarquias e poder; por isso, os jornais tornam-se importantes ferramentas de análise dos discursos por meio dos quais estereótipos são construídos e disseminados no tempo-espaço.

Como aponta Hansen (2006), a língua pertence à dimensão social, política e cultural de uma sociedade. A língua representa um sistema instável por meio da qual, sinais são evidenciados a partir da construção da identidade e da diferença. Por intermédio da linguagem, é possível enxergar as implicações do discurso político, marcado por construções específicas e subjetividades. Os meios de comunicação, na medida em que trabalham com diversos tipos de linguagem, atuam de modo ambíguo. Portanto, para refletir sobre a linguagem discursiva, é preciso observar o local de produção, reprodução de particulares subjetividades e identidades e, ao mesmo tempo, observar as exclusões e os silenciamentos produzidos pela BBC e pela Dabiq Magazine.

Ao refletir sobre a análise do campo discursivo, necessitamos compreender o enunciado a fim de refletir as estreitezas e as singularidades com que a mensagem está sendo proposta. A análise de discurso, assim, possibilita demarcar as superfícies das primeiras emergências, as instâncias de delimitação, chegando inclusive às grades de especificação (FOUCAULT, 1997). De acordo com Doty (1993), a abordagem de práticas discursivas 
enfatiza a construção linguística da realidade. A natureza produtiva da linguagem não depende ou, tampouco, coincide necessariamente com as motivações, percepções, intenções ou entendimento dos atores sociais (MILLIKEN, 1999).

A análise de discurso, portanto, permite, ao longo do tempo, compreender que as práticas discursivas não são feitas com uma base de centro fixo e estável, mas constituem modos de subjetivação de forma dispersa e espalhados por vários locais. Por isso, neste artigo, optou-se pela análise de discurso foucaultiana arqueológica, uma vez que esta abordagem consiste em buscar definir não os pensamentos, as representações, as imagens, temas, as obsessões que se ocultam ou se manifestam nos discursos, mas os próprios discursos, enquanto práticas que obedecem a regras (FOUCAULT, 1997).

\section{A análise de discurso em perspectiva comparada: Dabiq Magazine e a BBC}

\section{Dabiq Magazine}

O artigo realizou análises sobre a Dabiq Magazine a partir da edição número 12, de 18 de novembro de 2015. A revista possui 66 páginas, porém, somente foram analisados, neste artigo, os conteúdos que faziam menção aos ataques em Paris. Assim, a análise foi realizada com base na capa, no prólogo, com suas fotos e legendas, e na matéria que se inicia na página 25 e termina na página 28. Cabe uma ressalva nesta análise: as imagens utilizadas pela Dabiq Magazine sobre o atentado de Paris foram retiradas das Agências de Notícias Internacionais e adulteradas de modo a desestabilizar e mesmo inverter os discursos históricos produzidos pelo Ocidente sobre o Oriente Médio. Neste sentido, a Dabiq utilizou-se de recursos fotográficos, tendo por objetivo determinar as composições fotográficas (legendas, cores, enquadramentos) segundo suas subjetividades e visões de mundo. Seguindo a ordem de apresentação dos conteúdos na revista, a primeira figura é a foto da capa.

Na imagem, é possível observar alguns sentidos produzidos pela capa. Cabe destacar, primeiramente, o título, “JUST TERROR”. Seu significado faz referência à Shari’ah (lei) de Allah seguida pelos militantes do Estado Islâmico. Um dos ensinamentos de Shari’ah é o decreto de que a punição deve atingir os cruzados beligerantes e vir de lugares inesperados por eles (BUNZEL, 2015; NAPOLEONI, 2015). A ideia de justiça inferida nesse discurso também pode ser associada aos ataques aéreos executados por tropas francesas em curso contra o califado, sendo, dessa maneira, uma punição justa aos olhos de Allah e no âmbito político-militar. 
Figura 1 - Capa Dabiq Magazine \#12
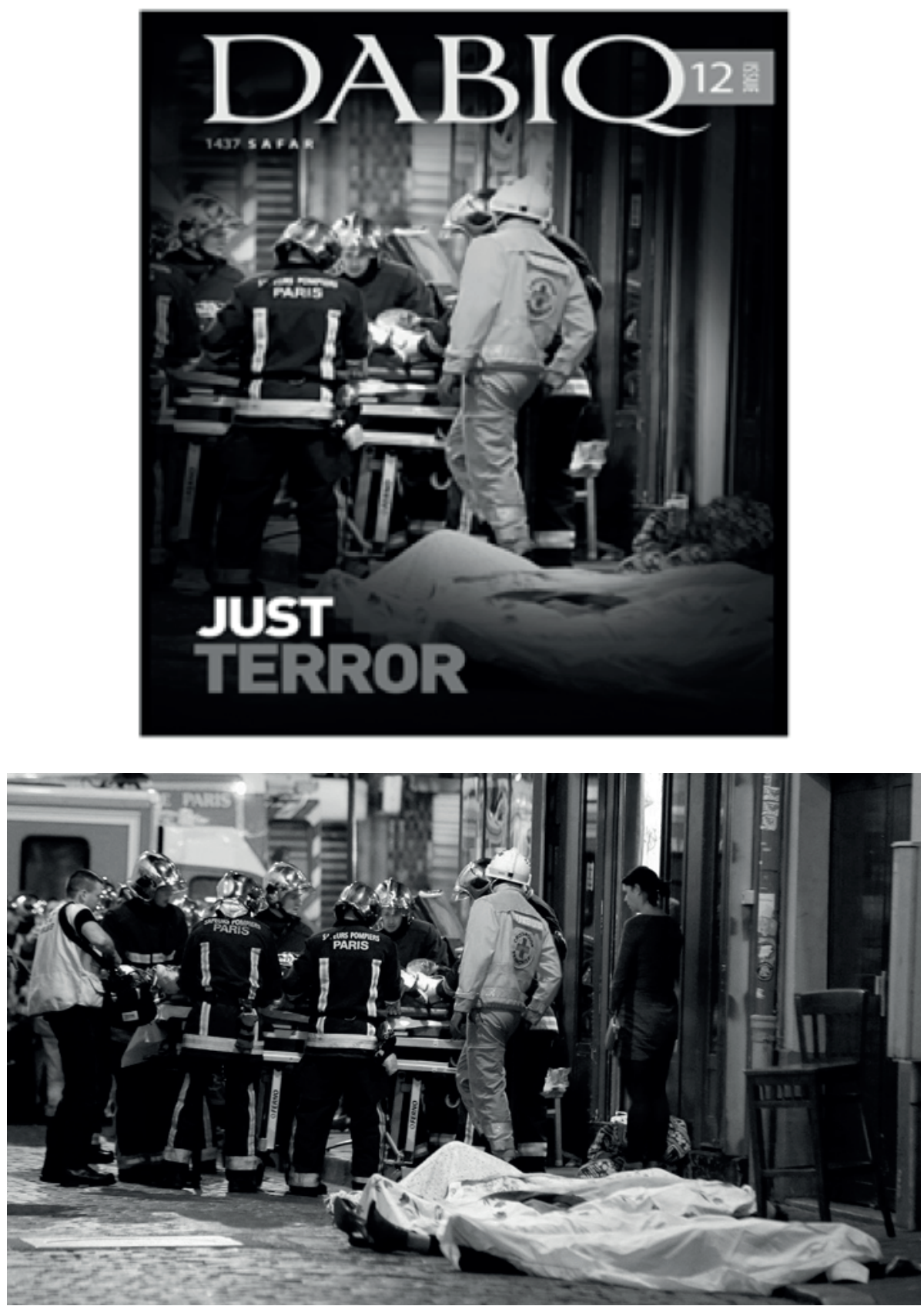

Fonte: Associated Press (AP). 
Uma segunda interpretação a partir desta análise discursiva corresponde às cores utilizadas no título. A palavra "terror" é destacada com o uso da cor vermelha, remetendo à agressividade e sangue. A palavra "just”, por sua vez, está em branco, transmitindo um sentimento de pureza, paz. Dessa forma, o que é relacionado ao “justo” é puro e com bênçãos, e o "terror" é um meio agressivo e sangrento de se chegar à justiça. Além disso, o título faz uso de letras em formato de caixa alta (letra maiúscula), prática que, na redação jornalística, funciona como uma maneira de chamar atenção.

No que concerne à foto, observa-se o escurecimento das bordas e o foco claro na pessoa que está sendo socorrida. Os bombeiros, com semblantes preocupados, revelam que o ataque promovido pelo grupo obteve êxito. A ação de ferir pessoas, e, principalmente, ferir psicologicamente também ganha destaque. A passagem escrita na página do prólogo pode apontar tal conclusão: "The divided crusaders of the East and West thought themselves safe in their jets as they cowardly bombarded the Muslims of the Khiläfah" (DABIQ MAGAZINE, 2015, p. 2). Uma quarta inferência quanto à foto é a sua alteração de modo a retirar a mulher que se encontrava no canto direito da imagem. A não utilização dos trajes “adequados” tais como o véu, pode ter sido a razão desta manipulação da imagem.

Quanto ao conteúdo do prólogo, que conta com uma parte textual rica e algumas fotos, destacamos alguns fragmentos que foram contextualizados e correlacionados com a Figura 1. Outro ponto que destacamos é relativo às outras fotos que fazem referência aos ataques de Paris. A Figura 2 tem como legenda “The coward François Hollande”. A importância dessa imagem deve-se, em termos contextuais, à figura do antigo presidente da França, François Hollande, eleito em 2012.

Figura 2 - Dabiq Magazine \#12, p. 2

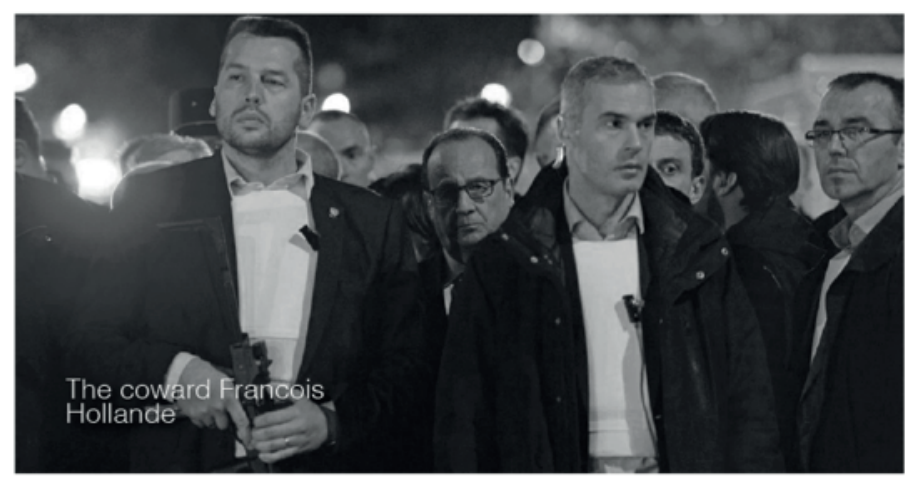

Fonte: Agence France-Presse.

Os dois homens em frente ao presidente são, aparentemente, seguranças, visto que um deles está armado; no entanto, é preciso observar que os indivíduos não estão uniformizados. Nesse sentido, a utilização do termo “covarde” dá-se em função de François Hollande estar 
escoltado (dependendo da interpretação, escondido, já que seu corpo mal pode ser visto e seu rosto está coberto pela sombra) por homens armados e utilizando coletes à prova de balas. Nota-se também que a paisagem ao redor dos homens está desfocada, fazendo com que a atenção/enquadramento se direcione para o centro, onde se encontra o presidente francês.

A Figura 3 possui a seguinte legenda: “The Scene after the Khilafah's daring raids in Paris” Na foto, pode-se contemplar a cena do restaurante La Belle Equipe após o ataque dos atiradores, com corpos no chão e ação dos bombeiros. A luz do refletor no rapaz destaca o rosto assustado, deixando o registro com uma grande carga dramática. Tal como a Figura 1, a Figura 3 aponta para os corpos ensanguentados, bombeiros e semblantes assustados, remetendo, mais uma vez, ao sucesso da ação por parte do grupo Estado Islâmico.

Figura 3 - Dabiq Magazine \#12, p. 2

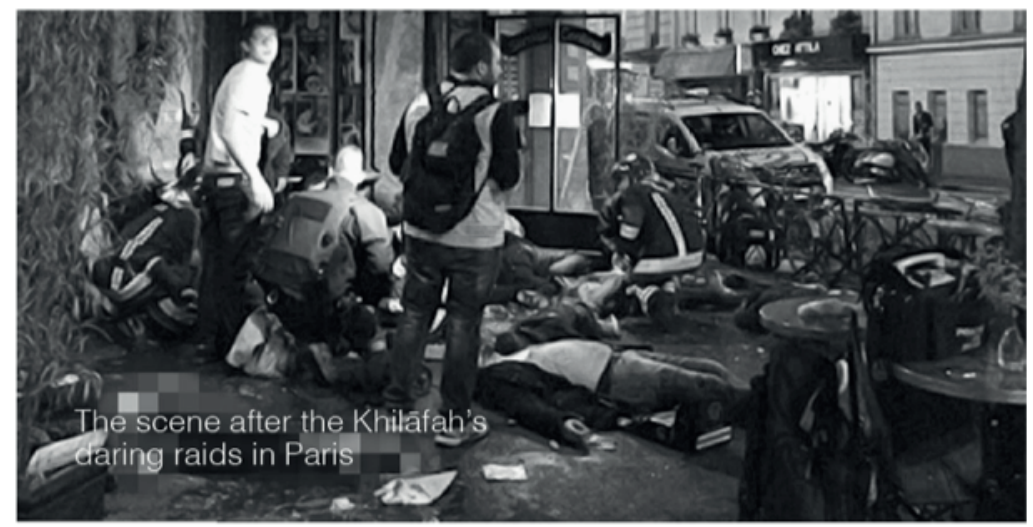

Fonte: Dabiq Magazine.

No que concerne às palavras, podemos ressaltar o uso da expressão daring (ousada). Segundo nossa interpretação, a expressão está relacionada às dificuldades do EI em avançar geopoliticamente pelo território europeu. Ao revisitarmos o prólogo, as palavras utilizadas pelo EI apontam que, apesar de a inteligência internacional estar em guerra contra o Estado Islâmico, os ataques contra a nação francesa foram executados com êxito. A palavra “incursão” também tem destaque, haja vista que a expressão tem conotação de uma ação militar que, por sua vez, nos remete à ideia de invasão. Outra informação vista no prólogo é a frase "oito guerreiros derrubaram Paris de joelhos, depois de anos de arrogância francesa perante o Islã”. Segundo nossa interpretação, a frase refere-se à existência de um estado de emergência nacional no qual as ações dos oito homens armados, somente com rifles de assalto e cintos explosivos, foram capazes de promover uma cena de guerra (DABIQ MAGAZINE, 2015, p. 2).

Na Figura 4, por sua vez, vemos a legenda: “The nightmare in France has only begun”. A foto de um homem com a camisa ensanguentada, acompanhado de um policial e falando 
ao celular com um rosto assustado, retrata o horror vivido pelos ataques. A ameaça na legenda, indicando que a França é um alvo do Estado Islâmico, muito se deve ao que já foi abordado na Figura 1 com relação aos ataques aéreos no território do califado. No texto do prólogo, há uma passagem que passa a sensação de orgulho sentida com o choque da população francesa: "Thus, the Islamic State dispatched its brave knights to wage war in the homelands of the wicked crusaders, leaving Paris and its residents shocked and awed|" (DABIQ MAGAZINE, 2015, p. 2).

Figura 4 - Dabiq Magazine \#12, p. 2

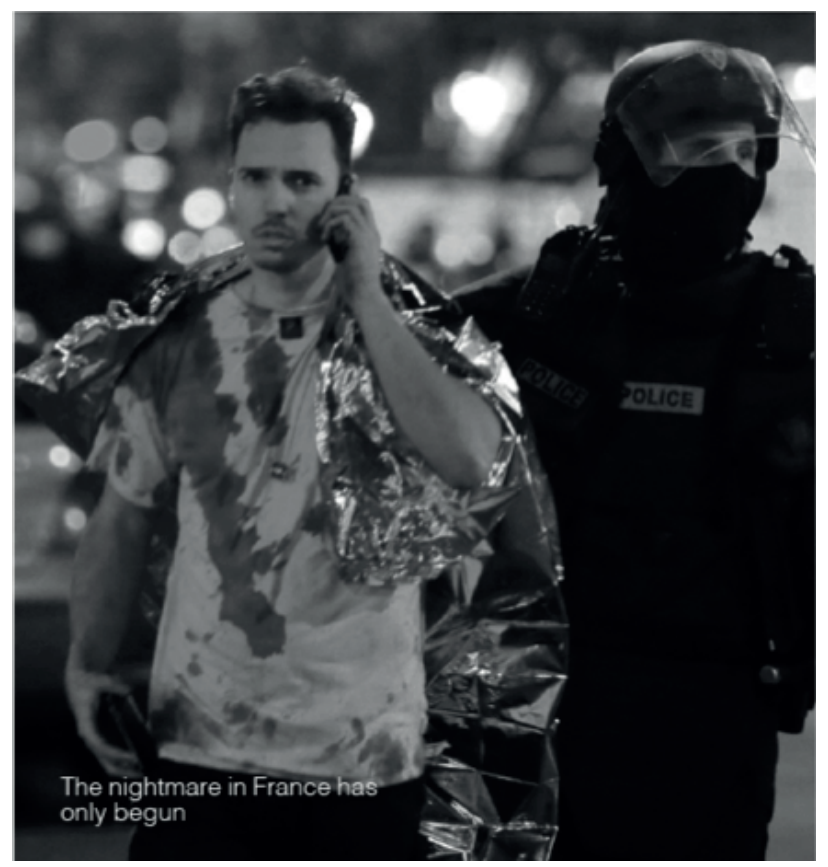

Fonte: Foto original Reuters.

Dando sequência ao conteúdo da edição \#12, em uma seção intitulada "A selection of military operations by the Islamic State”, são destacadas algumas operações conduzidas pelo grupo terrorista em diversas regiões do globo. Ressaltamos esta passagem da revista visto que existe a transmissão de um discurso em defesa das operações onde o grupo obteve-se êxito por intermédio de uma expansão geopolítica do território do califado. A expansão do califado pode ser também interpretada como um modo de massacrar, aterrorizar e humilhar os inimigos de Allah (DABIQ MAGAZINE, 2015, p. 25). Entre essas operações militares do grupo que deram “certo”, estão os ataques em Paris. 
Figura 5 - Dabiq Magazine \#12, p. 28

\begin{abstract}
France - On Friday, the $1^{\text {th }}$ of Safar, 8 soldiers of the Khilāfah carried out an operation in the heart of French crusader territory. The operation involved multiple simultaneous attacks with explosive belts and assault rifles on various targets including the Stade de France stadium, where the crusader president Francois Hollande was attending a soccer match, and the Bataclan theatre for exhibitions, where hundreds of French mushrikīn had gathered for a music concert. The attacks, which included other targets around Paris and succeeded in killing hundreds of crusaders and wounding even more, shook the world and reminded the nations of kufr that the Islamic State will continue to stand firm in the face of their transgressions and retaliate with fire and bloodshed in revenge for the honor of the Prophet and the multitudes killed and injured in crusader airstrikes in the lands of the Muslims.
\end{abstract}

Fonte: Dabiq Magazine.

A Figura de número 6 tem como legenda a seguinte descrição: "Carnage on the streets of Paris following the Islamic State's blessed assault”. Tal como as fotos analisadas anteriormente, a presença de elementos que mostram preocupação e/ou sensação de emergência/urgência reafirmam o impacto dos atentados terroristas. Uma outra observação é que uma das pessoas está desfocada na foto, neste caso é uma mulher e, provavelmente, esse procedimento foi feito pela mesma razão da Figura 1.

Figura 6 - Dabiq Magazine \#12, p. 28

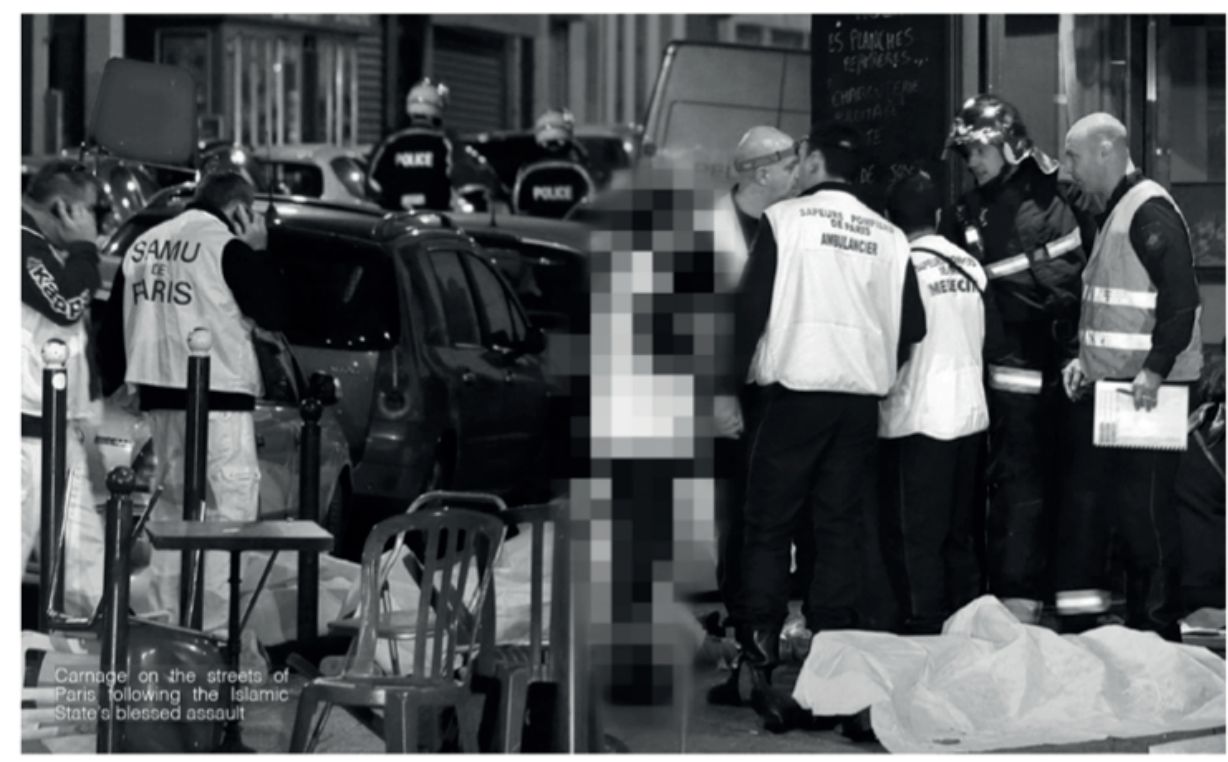




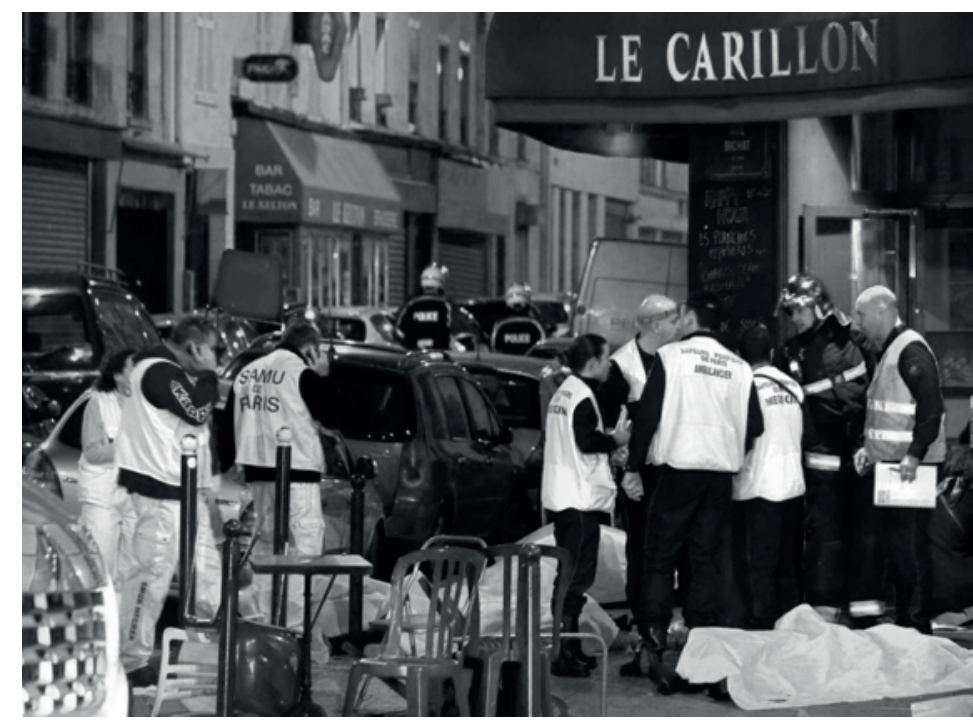

Fonte: Foto original da Reuters.

Os óbitos são associados aos cruzados que executaram ataques aéreos nas terras do califado. Realizada a análise da Dabiq, com suas nuances nos textos e fotos, é feito, a seguir, um estudo discursivo da BBC. Os mesmos objetivos e parâmetros foram abordados e respeitados desde a utilização de matérias, com fotos, textos e delimitação temporal.

\section{BBC}

A BBC realizou uma cobertura sobre os ataques de Paris do dia 13 de novembro (sexta-feira) até o dia 18 de novembro (quarta-feira), fazendo uso de material de outras agências de notícias internacionais. Além disso, diversas reportagens foram realizadas, e, desse modo, é possível encontrar, a partir de um sistema de busca do próprio site da emissora, vídeos de sobreviventes contando suas experiências e como conseguiram sair vivos dos locais atacados. Filmagens de celulares das vítimas ou dos vizinhos próximos aos locais dos atentados também foram utilizados. Alguns vídeos internacionais também foram citados nas matérias, tendo como enfoque o sentimento de solidariedade e compaixão às vítimas. As reportagens fizeram referência à utilização das redes sociais no mundo como forma de auxílio ou apoio aos franceses que foram atingidos pelos ataques, destacando, sobretudo, o Facebook, que possibilitava aos seus respectivos usuários que alterassem suas fotos nas cores da bandeira francesa (azul, branco e vermelho) com um lema “Je suis Paris”.

O estímulo às reportagens sobre os ataques propiciou que outras análises e histórias paralelas pudessem ser abordadas e/ou revisitadas. A alusão a outros ataques no mundo também foi endossada pela BBC. A temática da (in)segurança ganhou notoriedade, principalmente no que tange às questões envolvendo os refugiados que chegavam cada vez mais à Europa. $\mathrm{O}$ aumento de (in)segurança em vários países do continente também foi um 
tema levantado, sobretudo, no que é relativo à mudança da estratégia militar em ações contra o Estado Islâmico. Entretanto, apesar de ser importante citar essas matérias, o enfoque do artigo reside na análise textual e fotográfica que compõe a matéria jornalística que versa especificamente sobre os ataques.

A primeira fonte é do dia 14 de novembro de 2015, com o título "Paris attacks: Islamic State militants change tactics”, do autor Frank Gardner, correspondente de segurança da BBC desde 2002, e vítima de um atirador na Arábia Saudita em 2004²2. O título da matéria explica-se tendo em vista que o grupo do EI passou a realizar ataques para além da região do Oriente Médio. Dirá Gardner (2015): "Mas os militantes estão bem cientes do seu apelo transnacional à violência jihadista na Europa e em outro lugar”. O uso da palavra “apelo”, dentro da mudança de tática, busca desqualificar a ação, já que tal palavra remete à uma ação tida como última instância, buscando chamar a atenção ao atacar o terreno europeu ou outros fora da região de influência direta do grupo.

As ações fora do território habitual são tratadas na matéria como consequência dos ataques aéreos na região dominada pelo grupo. Entretanto, os ataques são tidos como vitoriosos, já que buscam acabar com os líderes. Portanto, as novas ações passam a ser realizadas fora do centro de gravidade do Estado Islâmico, isto é, Iraque e Síria. Assim, no decorrer da reportagem, são abordados outros temas que buscam apresentar um pano de fundo para explicar a ação. Dentre eles, estão os ataques ocorridos em países do Oriente Médio, nos meses próximos a novembro de 2015, principalmente a emblemática questão fronteiriça entre Turquia e Síria. Essa região de fronteira ganha relevância, já que é o espaço onde transitam os jihadistas, advindos da Europa, para se juntar ao EI.

A reportagem, produzida pela BBC, possui três fotos; contudo, apenas duas abordam os ataques de Paris. A Figura 7 possui a seguinte legenda: "Security has been stepped up across France in the wake of the attacks". A foto de militares fortemente armados em um aeroporto faz a associação com as vias de entrada no país, visto que existe um conflito quanto à entrada de refugiados. A Figura 8, com a legenda "Across France and beyond, tributes are being paid the victims of the attacks", nos mostra dois rapazes grafitando, em um dos muros da cidade, a mensagem "Reze por Paris", que se espalhou pelas redes sociais, tornando-se amplamente conhecida.

22 Frank Gardner foi atingido seis vezes enquanto filmava uma casa de um militante da Al-Qaeda em junho de 2004. 
Figura 7 - Gardner (2015)

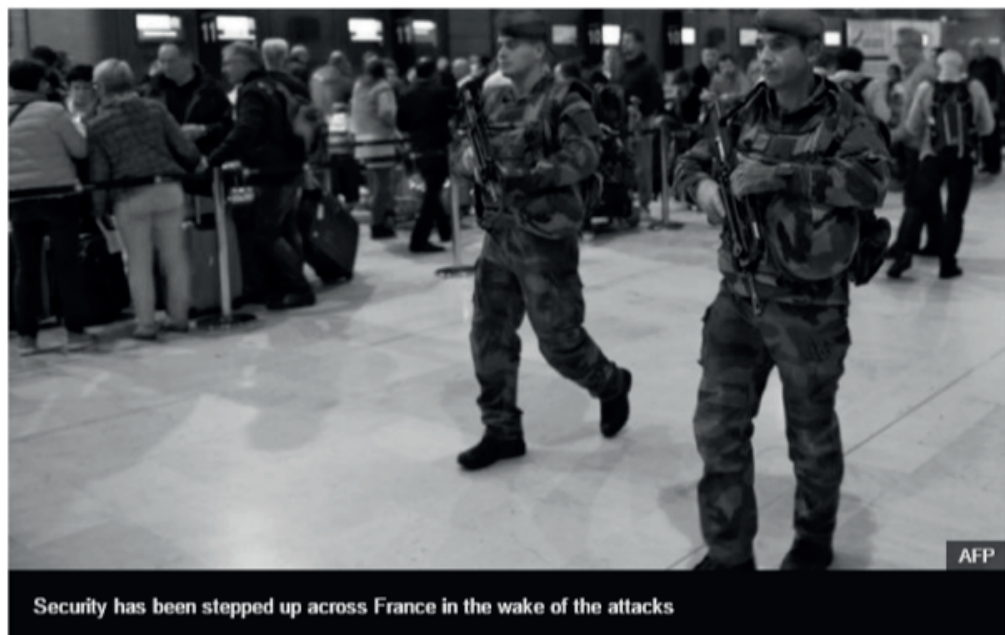

Fonte: Agence France-Presse.

Figura 8 - Gardner (2015)

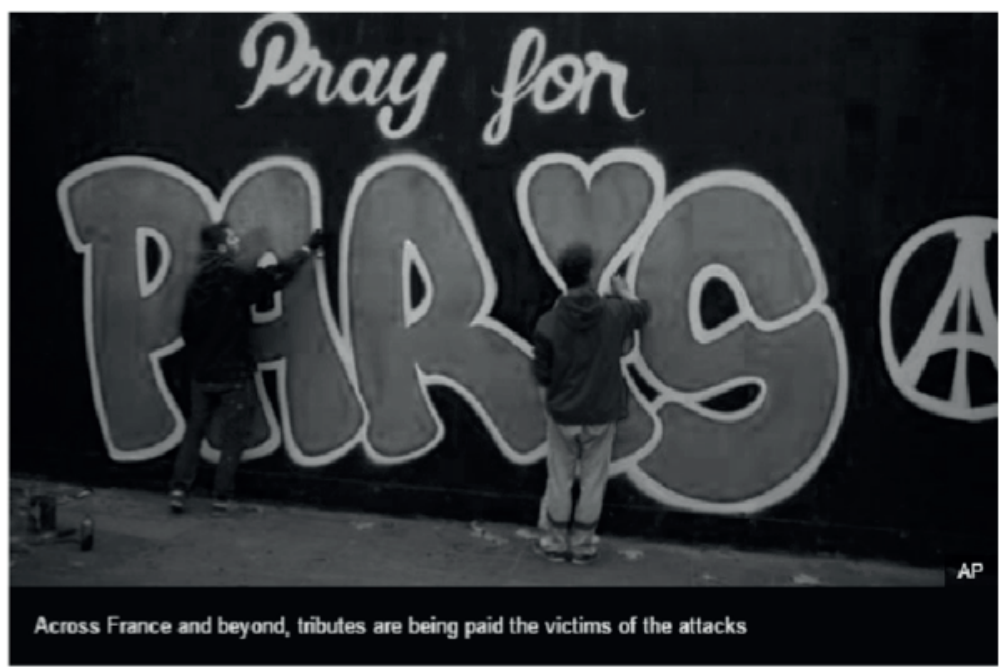

Fonte: Associated Press.

A próxima reportagem também é do dia 14 de novembro e possui o seguinte título: “Paris attacks: A new terrorism and fear stalks a city”. No começo da reportagem, há alusão aos ataques ao jornal francês Charlie Hebdo (janeiro de 2015). A correlação feita pelo jornal busca realizar um paralelo e uma comparação com o que aconteceu nas ruas de Paris em 
2015. O autor da matéria também destaca que os ataques - cuja ocorrência é considerada “normal” e associada ao Oriente Médio - chegaram à Europa, mais precisamente em Paris, cidade onde não existiria esse tipo de ferocidade.

Schofield (2015) informa que os ataques em Paris apontam para um novo tipo de terrorismo, caracterizado pela lacuna quanto às crenças, massivo e mortal. Por fim, Schofield (2015) fala sobre a (possível) reação da sociedade francesa (solidariedade), que clama pela retomada do armamento policial para aqueles que estão fora de serviço. Ao mesmo tempo, o autor aponta que os franceses também reivindicaram a volta do armamento na sociedade, que estava vivendo com medo e insegurança. De acordo com o autor, esse seria o principal objetivo dos perpetradores, isto é, deixar a sociedade francesa sob o medo, armada e dividida entre si.

A matéria também é composta por duas imagens (Figuras 9 e 10). Na primeira, a frente do restaurante que foi alvo do ataque está repleta de flores no chão, simbolizando o sentimento de solidariedade da sociedade francesa. Na segunda imagem, podem ser observados militares armados nas ruas de Paris, mais precisamente em frente à Catedral de Notre-Dame, uma igreja cristã e ponto turístico da cidade, onde existe a transmissão de uma mensagem de proteção, símbolo cristão.

Figura 9 - Schofield (2015)

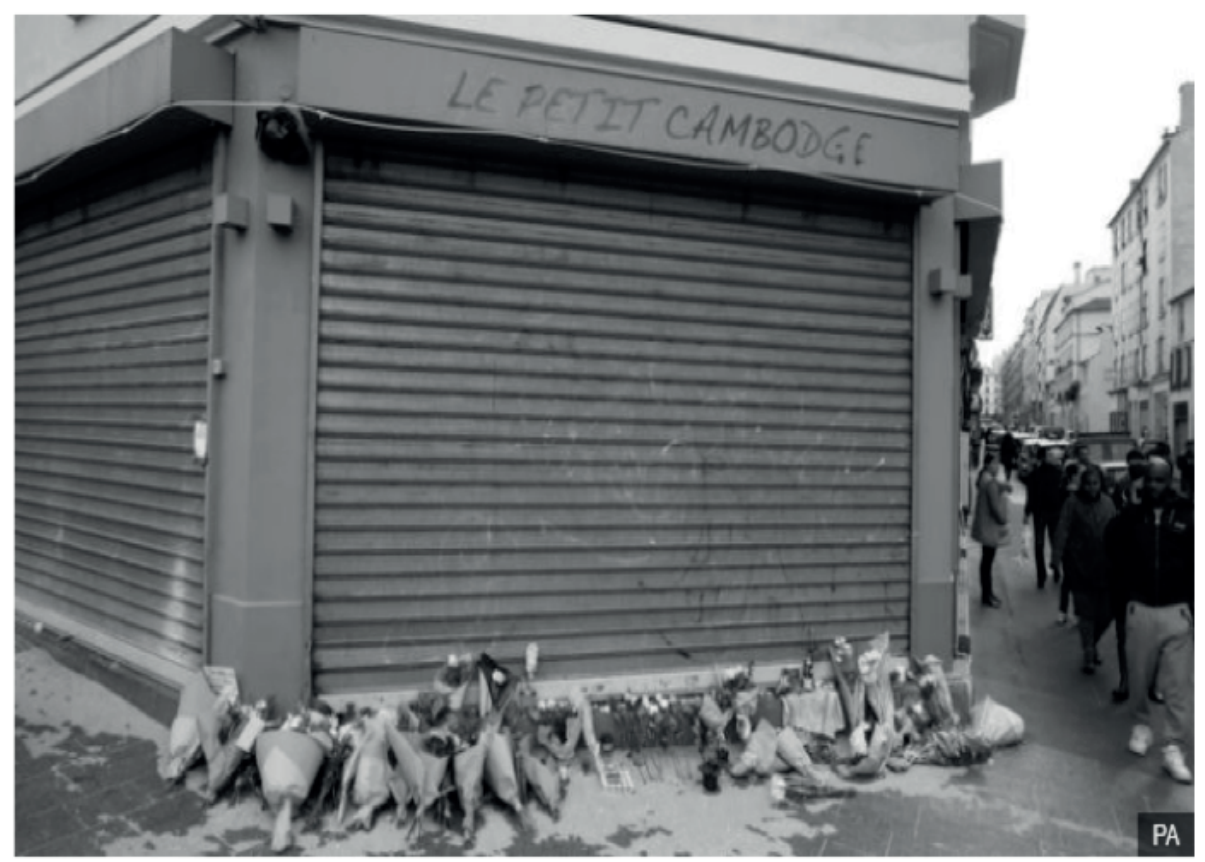

Fonte: Press Association. 
Figura 10 - Peter (2015)

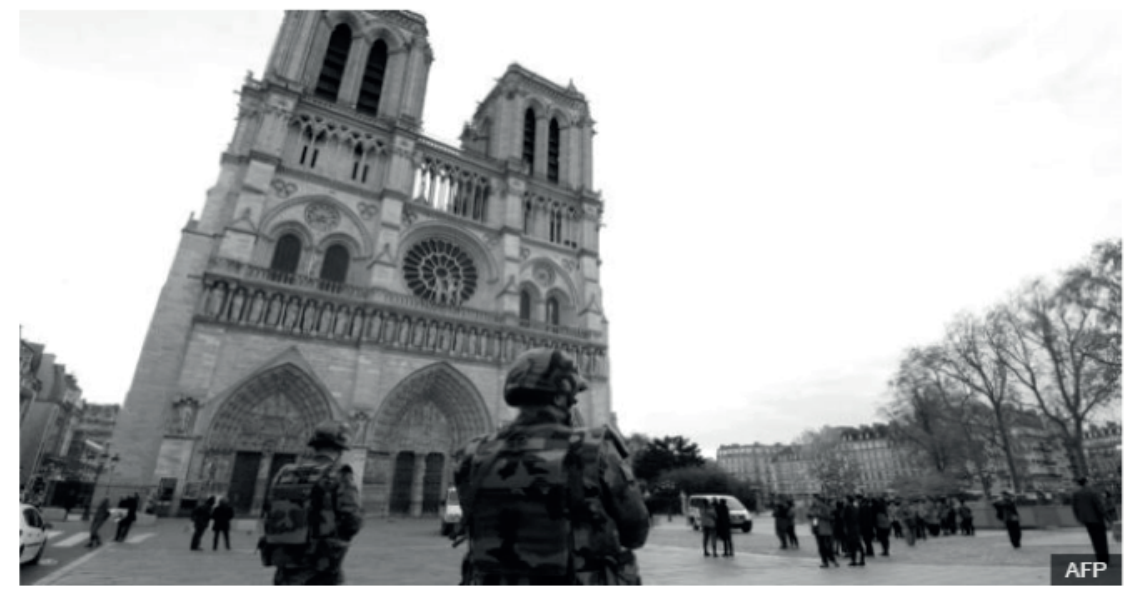

Fonte: Agence France-Presse.

Outra inferência que pode ser feita da matéria jornalística está relacionada à angulação e ao enquadramento. Na primeira foto, o ângulo é perpendicular ao local atingido, permitindo avistar a entrada com flores, o nome do restaurante e as pessoas passando na rua ao lado. Tal cena mostra o retorno à normalidade da vida cotidiana em contraste com os resquícios da tragédia (flores e o chão sujo, aparentemente de areia). Na segunda imagem, toda a imponência da Catedral de Notre-Dame é vista a partir do posicionamento de baixo para cima da câmera, com os militares armados protegendo sua base, e, no canto direito, existe uma aglomeração de pessoas que novamente retorna ao cotidiano daquela região turística.

A última reportagem do dia 14 de novembro de 2015, tal como a anterior, levanta o questionamento de um novo tipo de terrorismo em seu título: "Paris attacks: A new type of terrorism?”. Ao longo da reportagem, o jornalista Peter (2015) aponta questionamentos sobre os ataques em Paris, especialmente em relação aos motivos de tal cidade ter sido o alvo. Existe a hipótese de que o atentado constituiria uma retaliação aos ataques aéreos franceses contra o grupo na Síria e no Iraque, mas, nessa passagem, especificamente, os ataques na França não são usados para transmitir uma mensagem de vitória sobre o grupo.

O jornalista entende que a escolha dos alvos civis tinha como intenção matar o máximo possível de pessoas e de maneira aleatória. Na reportagem, é dito que na França esse tipo de barbárie não é comum, ao contrário de outros países do Oriente Médio, nos quais muitas das ações passam a impressão de naturalidade. Estão presentes, nessa mesma reportagem, três fotos, sendo que uma delas é o mapa que aponta onde aconteceram os ataques. A legenda "Police are on the highest alert as the hunt for possible accomplices continues" é acompanhada de uma foto na qual a viatura policial e a fita de isolamento ganham destaque. A legenda da fotografia transmite a mensagem de que a polícia está presente nas ruas de Paris e medidas estão sendo tomadas para a proteção dos cidadãos parisienses. 
Figura 11 - Peter (2015)
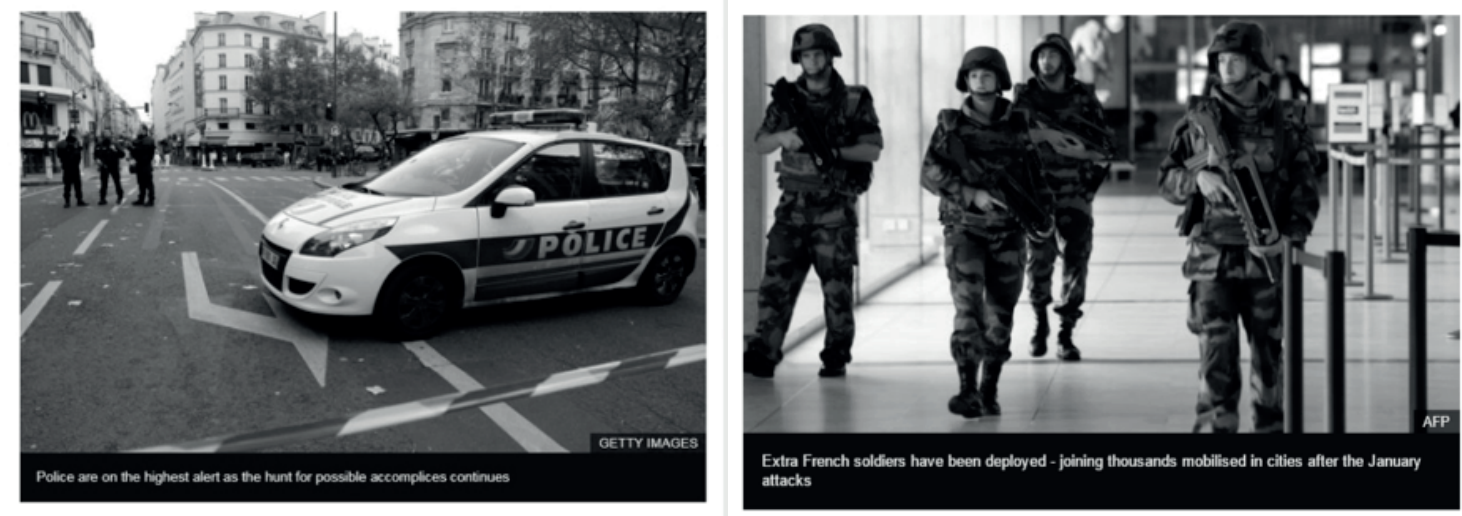

Fonte: Agence France-Presse.

Dando seguimento, a matéria do dia 18 de novembro de 2015, "Paris attacks: Grief, anger and defiance on city streets", trata especialmente dos parentes das vítimas e dos sobreviventes com seus respectivos depoimentos. A matéria de Burridge (2015) dissemina, também, em suas fotos, o sentimento de solidariedade que se espalhou por Paris e foi demostrada nos locais alvos. A Figura 12 tem, como legenda, as palavras: "The Bonne Biere was one of the venues targeted in Friday's attacks”. Ainda que a localização seja diferente, as flores mantêm a mesma intenção. É preciso destacar que, nesta imagem, há um cidadão francês que lê e faz referência às homenagens prestadas pelos diversos cidadãos franceses.

Figura 12 - Burridge (2015)

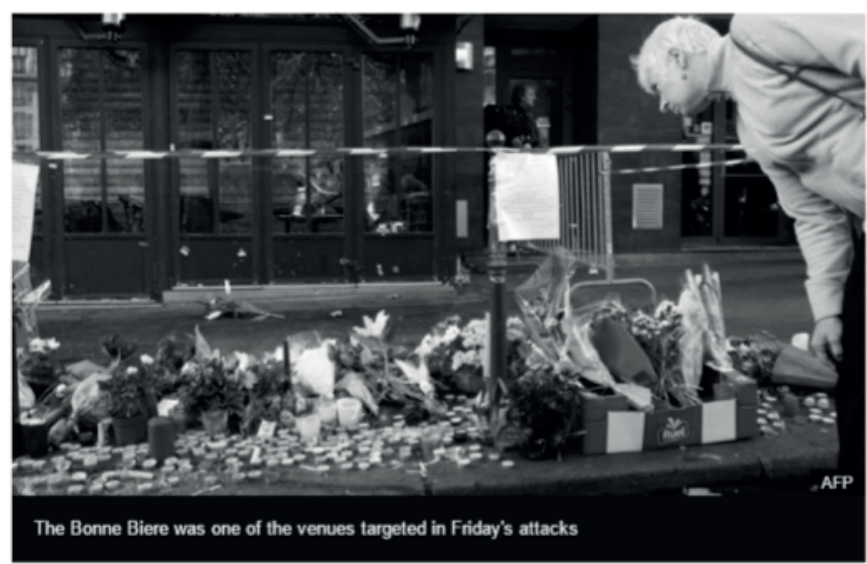

Fonte: Agence France-Presse.

O mesmo ocorre com a Figura 13, que tem como legenda "Flowers and tributes have been left outside Le Carillon bar in Paris”. A foto com a rosa, um símbolo do amor, é 
focalizada e, em seu entorno, todas as demais flores, ocupando metade da imagem, reforçam, em nosso entendimento, a mensagem de amor e de solidariedade para com a sociedade francesa. Por fim, na última imagem, "The attacks have left the people of Paris in shock", tal referência se mantém, mas de outro modo: além das inúmeras flores, também é colocada em destaque a foto de duas mulheres que, possivelmente, foram vítimas. A mensagem de empatia, dessa forma, torna-se, ainda, impactante visto que mostra de modo nítido os rostos das duas jovens vítimas.

Figura 13 - Burridge (2015)

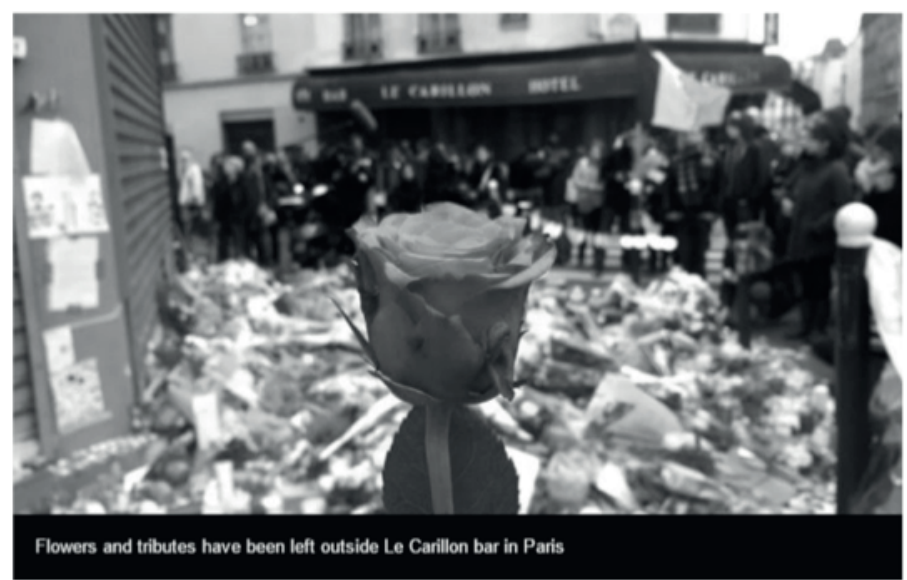

Fonte: Agence France-Presse.

Figura 14 - Burridge (2015)

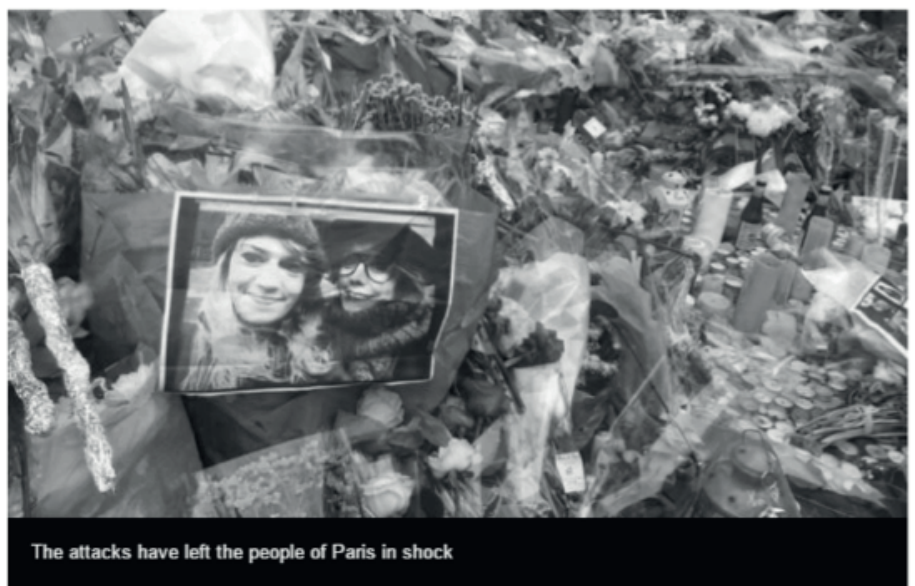

Fonte: Agence France-Presse. 


\section{Diferenças e Semelhanças entre a BBC e a Dabiq Magazine: a lógica da estratégia discursiva}

Ao refletirmos sobre a BBC, observamos que há uma (re)produção discursiva a partir do conceito de "salvação" que a Europa e os EUA realizam rotineiramente sobre os demais países/regiões vistos como vilões/inimigos. Segundo os valores éticos e morais ocidentais, as mídias e seus respectivos Estados buscaram cristalizar, no imaginário social, no transcorrer do tempo/espaço, imagens caracterizadas por estereótipos que conotem/denotem ideias sobre “vilões”/“inimigos”. Neste enquadramento discursivo, há também uma exaustiva (re) produção patológica que é disseminada sobre o terror e o terrorismo produzidos pelo EI e que, por sua vez, é diretamente associado a outros grupos que produzem ações terroristas (e que detêm outras dinâmicas e estratégias, ainda que o intuito seja semelhante, mas não igual) e ao Oriente Médio no que concerne suas estratégias e seus mecanismos de difusão de conteúdo.

Como forma de combater as ideias do EI, associadas ao terror e ao terrorismo, a $\mathrm{BBC}$, mediante os conteúdos jornalísticos no dia a dia, transmite ideias/valores segundo a lógica de "segurança”, "solidariedade” e retorno à "normalidade” calcadas nos valores (regras) ocidentais considerados universais, visualizadas nos textos escritos e nas imagens que estão neste artigo. Por mais que a BBC produza discursos que construam um imaginário em defesa da "segurança”, "solidariedade” e retorno a "normalidade”, a rede britânica, em seus múltiplos canais de comunicação, também reproduz imagens onde as sensações de insegurança, desespero e de caos são visualizadas.

De um modo geral, a BBC constrói, no imaginário social, discursos que buscam evocar imagens que estejam associadas às ideias de progresso (telos). Como diria Foucault (1997), um continuum discurso inspirado nas visões darwinistas sobre a teoria da evolução é construído sob a história ocidental. Para o filósofo francês, faz-se necessário desestabilizar as histórias que as ciências humanas, no âmbito da modernidade, universalizaram sobre as múltiplas sociedades. Nesse sentido, romper com os discursos evolucionistas, teleológicos, é apontar o discontinuum. Em outras palavras, não há linearidade nas histórias políticas, sociais e econômicas sobre a humanidade.

Aqui, cabe uma ponderação. Diferentemente da BBC, o EI, via Dabiq Magazine, atesta que o Ocidente "esquece” dos diversos genocídios realizados pelos perpetradores europeus e norte-americanos, autorizados direta e indiretamente em diversos momentos históricos sobre o Oriente Médio e suas populações. A Dabiq, ao evocar as imagens das guerras pela independência dos países do Oriente Médio, as histórias/imagens sobre as operações de paz/intervenções humanitárias feitas pelo Ocidente sobre o Oriente Médio, demonstra que, sob o discurso da "paz", do "progresso", da "democracia”, o Ocidente rotineiramente tenta "apagar” da "memória” da comunidade internacional as atrocidades que cometeu no passado e que repete no cotidiano sobre a região/países. 
Além disso, cabe destacar, também, que a Dabiq Magazine, por meio de seus discursos, produz sensações de insegurança, desespero e de caos tanto quanto a BBC. E, por meio de seus discursos, buscam resgatar, a partir de suas perspectivas políticas, um retorno a "normalidade”, "segurança” e "solidariedade”. Esses resgastes via "normalidade" que o EI constrói, por meio da Dabiq, são amparados em seus respectivos regimes de verdade por meio dos discursos projetados. Os regimes de conhecimento, verdade e poder produzidos pela Dabiq têm por objetivo desestabilizar o imaginário internacional que há sobre o Oriente Médio. As essencializações produzidas sobre os árabes, demonstradas por meio de documentos e imagens, atestam e reiteram que o Ocidente, por meio de múltiplos processos de colonialidade, continua a exercer violências sob diversas formas sobre as populações dos países do Oriente Médio.

Como mencionado na seção três deste artigo, todas as fotos utilizadas pela Dabiq Magazine foram extraídas das Agências de Notícias Internacionais e, por seguinte, adulteradas segundo os interesses do EI. As cores utilizadas nas imagens, as legendas, os ângulos escolhidos, as composições fotográficas, de um modo geral, selecionadas pelos jornalistas e seus representantes de ambos os meios de comunicação (BBC e Dabiq), buscam não apenas determinar a leitura do internauta/leitor, mas tentam disseminar a partir dos discursos suas compreensões de mundo (ainda que nem sempre consigam).

Já apontava Barthes (2015) que as fotografias jornalísticas são mensagens caracterizadas pelos sentidos denotativo e conotativo, pelo óbvio e obtuso sendo, portanto, paradoxais. Porém, ainda que paradoxais, as fotografias se comunicam com os públicos (não mais passivos), a partir da emissão e recepção da mensagem transmitida. Nesse sentido, produzir conteúdo midiático, dirá Barthes (2015) é estudar os grupos humanos, definir seus motivos, atitudes, ligar o comportamento destes grupos à sociedade ao qual fazem parte. Portanto, compreender a mensagem fotográfica (discurso) é realizar uma análise sociológica e mesmo filosófica.

Ao resgatarmos Foucault (1997, 2017a, 2017b, 2017c) e suas reflexões sobre o conceito de discurso, em paralelo a Barthes (2015), refletimos que tanto a Dabiq quanto a BBC apresentam, em seus enunciados, regimes de conhecimento, verdade e poder que são antagônicos e, ao mesmo tempo, verossimilhantes, já que buscam convencer a opinião pública internacional a partir de seus respectivos valores segundo a valorização da cultura da insegurança (WELDES et al, 1999). Todavia, cabe também destacarmos que, especificamente, no caso da BBC, a mesma está sob o amparo de Estados e Instituições Internacionais que legitimam e normalizam certas práticas de violência, ao mesmo tempo em que negligenciam outras práticas tão violentas quanto, enquadrando-as como exceção a exemplo do EI. Estas últimas precisam ser ceifadas ou retornadas às regras/leis (força de lei) aceitas socialmente.

Em todos os casos analisados, isto é, tanto a BBC quanto a Dabiq, observamos que os discursos produzem diversas formas de violência e terrorismos, sobretudo as simbólicas, representadas pelos conteúdos utilizados e disseminados pelas mídias. Portanto, em ambos os objetos analisados, buscamos, segundo a lógica da estratégia foucaultiana (1997), estabelecer 
quais conexões possíveis podem ser observadas entre termos díspares (BBC e Dabiq Magazine) e que continuam a ser díspares. A lógica da estratégia é a lógica da conexão com o heterogêneo e não com a lógica da homogeneização do contraditório. Além disso, em todos os conteúdos que foram produzidos pelos dois meios de comunicação online, tanto os terrorismos e os terroristas, como são enquandrados, são construídos segundo uma lógica misógina e hetenormativa. Não qualquer ponderação quanto as questões raciais, étnicas, gênero e classe, pelo contrário, os dicursos evocados e legitimados nas mídias sobre os terrorismos reforçam a misogenia e a naturalização e normalização da hetenormatividade, portanto, não tensionam as questões envolvendo gênero e terrorismos como bem aponta Puar (2017).

\section{Considerações finais}

O artigo tratou, a partir de uma perspectiva comparada, os diversos discursos midiáticos produzidos sobre o atentado em Paris no dia 13 de novembro de 2015, produzidos pela BBC e pela Dabiq Magazine, segundo a metodologia da análise de discurso foucaultiana. Como já mencionado neste artigo, os discursos verbal e não verbal dos meios de comunicação são caracterizados por ambiguidades por meio dos múltiplos jogos de linguagens. Em ambas as mídias, observamos que existe a transmissão de ideias e valores mediante a lógica de "segurança”, "solidariedade” e retorno à "normalidade” e, ao mesmo tempo, de modo não excludente, há a construção da sensação de insegurança, de tragédias e de desespero a partir da relação identidade/diferença.

Compreendemos que tanto a Dabiq (Estado Islâmico) quanto a BBC, em seus respectivos discursos, produzem seus regimes de conhecimento, verdade e poder que são antagônicos e ao mesmo tempo verossimilhantes, na medida em que buscam cooptar a opinião pública. Mesmo porque, como já mencionado no artigo, todas as fotos utilizadas pelas mídias advieram das agências de notícias internacionais. A diferença em cada mídia deu-se pelas composições, adulterações que as imagens sofreram ao serem construídas e disseminadas. Destacamos que enquanto a BBC, emissora britânica, está amparada sob a lógica Ocidental, por meio dos Estados e Instituições Internacionais, conseguindo, portanto, legitimar, normalizar e normatizar certas práticas de violência e terrorismos, o mesmo não ocorre com a Dabiq Magazine.

Ao suprimir as práticas discursivas sobre o EI, produzidas pela Dabiq Magazine, e compreendê-las como exceção, o Ocidente, via BBC, não foi invibializado de produzir discursos caracterizados por diversas formas de violência por meio de normas/força de lei que rotineiramente são normalizados e normatizados e, portanto, considerados “legítimos”. Os discursos heteronormativos também visualizados nos enquadramentos midiáticos sobre o terror e as ações/práticas terroristas, em ambos os meios de comunicação, são outra forma de disciplinar, vigiar e controlar os públicos a partir de um certo tipo de naturalização e normatização por meio da violência ao considerarmos as questões sobre a temática de gênero que permanecem sendo silenciadas e portanto, não problematizadas. 
(IN)SEGURANÇAS E TERRORISMOS: UM ESTUDO COMPARADO ENTRE AS MÍDIAS

ONLINE BBC E A DABIQ MAGAZINE A PARTIR DOS ATAQUES EM PARIS

\section{Referências}

ALTHEIDE, D. Terrorism and the Politics of Fear. Lanham, MD: Altamira Press, 2006.

ARADAU, C. et al (Ed.). Critical Security Methods: New frameworks for analysis. New York: Routledge, 2015.

BALZACQ, T. A Theory of Securitization: Origins, core assumptions, and variants. In: BALZACQ, T. Securitization Theory. Londres: Routledge, 2011.

BARTHES, R. O Óbvio e o Obtuso. Portugal: Edições 70, 2015.

BIGO, D.; TSOUKALA, A. Terror, Insecurity and Liberty: Illiberal practices of liberal regimes after 9/11. London and New York: Routledge, 2008.

BOOTH, K. Theory of World Security. Cambridge: Cambridge University Press, 2007.

BUNZEL, C. From Paper State to Caliphate: the ideology of the Islamic State. Washington DC: Brookings Institution, 2015. Disponível em: https:/www.brookings.edu/wp-content/uploads/2016/06/The-ideology-ofthe-Islamic-State.pdf. Acesso em: 27 out. 2016.

BURRIDGE, T. Paris attacks: grief, anger and defiance on city streets, 2015. Elaborada por BBC News. Disponível em: http://www.bbc.com/news/world-europe-34853915. Acesso em: 18 maio 2017.

BUZAN, B.; HANSEN, L. The Evolution of International Security Studies. Cambridge University Press, 2009.

BUZAN, B.; WEAVER, O.; WILDE, J. Security: a new framework for analysis. USA: Lynne Rienner Publishers, 1998.

COCKBURN, P. A Origem do Estado Islâmico: o fracasso da guerra ao terror e a ascensão jihadista. São Paulo: Autonomia Literária, 2015.

DABIQ MAGAZINE [s.l.]: Al- Hayat Media Center, v. 12, 2015. Disponível em: https://azelin.files.wordpress. com/2015/11/the-islamic-state-e2809cdc481biq-magazine-12e280b3.pdf. Acesso em: 20 maio 2017.

DEBRIX, F. Tabloid Terror: war, culture and geopolitics. London and New York: Routledge, 2008.

DEVETAK, R. Theories, Practices and Postmodernism in International Relations. Cambridge Review of International Affairs, v. 12, n. 2, p. 61-76, 2007.

DOTY, R. L. Foreign Policy as Social Construction: a post-positivist analysis of U.S. counterinsurgency policy in the philippines. International Studies Quarterly v. 37, p. 297-320, 1993.

FOUCAULT, M. A Arqueologia do Saber, 5. Ed., Rio de Janeiro: Editora Forence Universitárias, 1997.

FOUCAULT, M. Verdade e Poder. In: FOUCAULT, M. Microfísica do poder, 5. Ed., São Paulo: Editora Paz \& Terra, 2017a.

FOUCAUlT, M. Soberania e Disciplina. In: FOUCAULT, M. Microfísica do poder, 5. Ed., São Paulo: Editora Paz \& Terra, 2017b.

FOUCAUlT, M. Aula de 17 de março de 1976. In: FOUCAULT, M. Em Defesa da Sociedade. São Paulo: Editora Martins Fontes, 2017c.

GARDNER, F. Paris attacks: Islamic State militants change tactics. 2015. Elaborada por BBC News. Disponível em: http://www.bbc.com/news/world-europe-34824375. Acesso em: 18 maio 2017.

GOFFMAN, I. Frame Analysis: an essay on the organization of experience. Northeastern University Press, 2016. 
HANSEN, L. Security as Practice: discourse analysis and the Bosnian war. London: Routledge, 2006.

HANSEN, L. Theorizing the image for Security Studies: visual securitization and the Muhammad Cartoon Crisis. European Journal of International Relations, v. 17, n. 51, 2011.

HELD, D.; MCGREW, A. Globalization/anti-globalization: beyond the great divide. Cambridge, UK Malden, Massachusetts: Polity Press, 2002.

HODGES, A. The "War on Terror" Narrative: discourse and intertextuality in the construction and contestation of sociopolitical reality. New York: Oxford University Press, 2011.

HUYSMANS, J. The Politics of Insecurity: fear, migration and asylum in the EU. Londres: Routledge, 2006.

HUYSMANS, J.; SQUIRE, V. Migration and Security. In: CAVELTY, M. D.; MAUER, V. The Routledge Handbook of Security Studies. London and New York: Routledge, 2009.

JACKSON, R; SMYTH, M. B.; GUNNING, J. Critical Terrorism Studies: a new research agenda. USA: Routledge, 2009.

JACKSON, R. Writing the War on Terrorism: language, politics and counterterrorism. Manchester, UK: Manchester University Press, 2004.

JACKSON, R. Critical Terrorism Studies: an explanation, a defence and a way forward. Paper prepared for the BISA Annual Conference, 14-16 December, 2009a.

JACKSON, R. Knowledge, power and politics in the study of political terrorism. In: JACKSON, R.; SMYTH, M. B.; GUNNING, J. Critical Terrorism Studies: a new research agenda. USA: Routledge, 2009b.

KALDOR, M. Old and News Wars: organized violence in a global era, 3. Ed. Stanford University Press, 2016.

KRAUSE, K.; WILLIAMS, M. C. Critical Security Studies: concepts and cases. Minessota of University, 1997.

LEONARD, S.; KAUNERT, C. Reconceptualizing the audience in securitization theory. In: BALZACQ, T. Securitization Theory. London, Routledge, 2011.

McDONALD, M. Emancipation and Critical Terrorism Studies. European Political Science, v. 6, n. 3, p. 252-259, 2007.

MILLIKEN, J. The Study of Discourse in International Relations: a critique of research and methods. European Journal of International Relations, v. 5, p. 225-254, 1999.

NAPOLEONI, L. A fênix islamista: o Estado Islâmico e a reconfiguração do Oriente Médio. Rio de Janeiro: Bertrand Brasil, 2015.

NEOCLEOUS, M. Critique of Security. Montreal, McGill Queen's University Press, 2008.

OLIVERIO, A. The State of Terror. NY: State University of New York, 1998.

PETER, L. Paris attacks: A new type of terrorism?. Elaborada por BBC News. Disponível em: http://www. bbc.com/news/world-europe-34820847. Acesso em: 18 maio 2017.

PISOIU, D.; HAIN, S. Theories of Terrorism: an introduction. Routledge, 2018.

PUAR, J. K. Terrorist assemblages: homonationalism in queer times. Duke University Press, 2017.

REINHARDT, M. Violence. In: BLEIKER, R. Visual Global Politics. Routledge, 2018.

SALTER, M.; MUTLU, C. E. Research Methods in Critical Security Studies. New York: Routledge, 2013. 
SCHOFIELD, H. Paris attacks: A new terrorism and fear stalks a city. 2015. Elaborada por BBC News. Disponível em: http://www.bbc.com/news/world-europe-34821164. Acesso em: 27 dez. 2016.

SHAPIRO, M. Cinematic Geopolitic. New York: Routledge, 2009.

SLAUGHTER, A.; HALE, T. Transgovernmental Networks and Emerging Powers. In: S. ALEXANDROFF, A.; COOPER, A. F. Rising States, Rising Institutions: challenges for global governance. Brookings Institution Press, 2010.

STAMPNITZKY, L. Disciplining Terror. Cambridge, Cambridge University, 2013.

STEPANOVA, E. Terrorism and Antiterrorism. In: KALDOR, M.; RANGELOV, I. The Handbooks of Global Security policy. New York, 2014.

STUMP, J. L.; DIXIT, P. Critical Terrorism Studies: an introduction to research methods. New York: Routledge, 2013.

VULTEE, F. Securitization as a media frame: what happens when the media `speak security'. In: BALZACQ, T. Securitization Theory. Londres: Routledge, 2011.

WEAVER, O. Aberystwyth, Paris, Copenhagen New 'Schools' in Security Theory and their Origins between Core and Periphery. International Studies Association, Montreal, March, p. 17-20, 2004.

WELDES, J. et al (Ed,); Culture of Insecurity: states, communities, and the production of the danger. Minessota of University, 1999.

\section{Pablo Victor Fontes}

Doutorando em Relações Internacionais pelo Instituto de Relações Internacionais da Pontifícia Universidade Católica do Rio de Janeiro (IRI/PUC-RIO). Mestre pelo Programa de Pós Graduação em Relações Internacionais pela Universidade do Estado do Rio de Janeiro (PPGRI/UERJ)2017. Bacharel em Jornalismo pela Universidade Federal de Sergipe (UFS) - 2012. Bacharel em Comunicação Social - Audiovisual pela Universidade Federal do Rio de Janeiro (UFRJ) -2011. Estive enquanto Professor Colaborador do Instituto de Relações Internacionais e Defesa (IRIDUFRJ) (2018) e da Escola de Comunicação da Universidade Federal do Rio de Janeiro (2015-2017). Fui Professor da Faculdades Integradas Hélio Alonso (Facha)- 2018. Ganhei em Primeiro Lugar o Prêmio FUJB em Extensão Universitária UFRJ-2011. Durante (2013-2016) estive enquanto assistente de pesquisa pelo LABMUNDO- Laboratório de Análise Política Mundial e do LEMEP Laboratório de Estudos de Mídia e Esfera Pública (2015-2016). Atualmente, estou como pesquisador pelo grupo de pesquisa Integração Sul: autonomia e desenvolvimento (UFRJ). Vice -Coordenador do Laboratório dos Estudos de Mídia e Relações Internacionais (LEMRI/UFRJ). Filiado à Associação Brasileira de Relações Internacionais (ABRI), à Associação Brasileira de Estudos de Defesa (ABED), a Associação Brasileira de Ciência Política (ABCP), a Latin American Studies Association (LASA) e a International Studies Association (ISA), da Sociedade Brasileira de Estudos Interdisciplinares da Comunicação (Intercom) e da Associação Brasileira de Pesquisadores em Jornalismo (SBPJOr). Temas de Interesse: Segurança Internacional, Questões Humanitárias, Pós-Colonialismo, Mídia, Estética, Cultura e Relações Internacionais. E-mail: pablovictorfontes@gmail.com. 


\section{Monica Herz}

Possui doutorado em Relações Internacionais pela London School of Economics and Political Science (1994). Atualmente é professora associada do Instituto de Relações Internacionais da Pontifícia Universidade Católica do Rio de Janeiro (PUC-Rio). Tem experiência na área de Relações Internacionais, com ênfase em Segurança Internacional, atuando principalmente nos seguintes temas: Política Internacional, Organizações Internacionais, Segurança Internacional, Relações Internacionais da América Latina e Política Externa Brasileira. É Cientista do Nosso Estado da Faperj desde 2012 e bolsista de produtividade do CNPq. É autora de “Organizações Internacionais: histórias e práticas” (em co-autoria com Andréa Ribeiro Hoffman e Jana Tabak) (Rio de Janeiro: Elsevier, 2004); "Ecuador vs. Peru: Peacemaking Amid Rivalry" (em co-autoria com João Pontes Nogueira) (Boulder, CO: Lynne Rienner Publishers, 2002); e "The Organization of American States (OAS): Global Governance Away from the Media” (London: Routledge, 2010). Publicou diversos capítulos de livros por editoras internacionais e artigos em periódicos no Brasil e no exterior. Atualmente está envolvida em pesquisa sobre o fluxo de armas na América Latina, governança regional e política de segurança internacional brasileira. Possui larga rede de cooperação internacional para o estudo e pesquisa na área de relações internacionais. E-mail: herz@puc-rio.br.

\section{Jéssika Cardoso de Medeiros}

Mestranda em Comunicação pelo Programa de Pós-Graduação em Comunicação da Universidade Federal Fluminense (PPGCOM/UFF). Bacharel em Defesa e Gestão Estratégica Internacional pela Universidade Federal do Rio de Janeiro (UFRJ). Cursando graduação em Direito na Faculdade Nacional de Direito (UFRJ). Membro do corpo editorial da equipe de Tradução na Revista Contracampo (PPGCOM/UFF). Faço Estágio jurídico no Centro de Proteção a Refugiados e Imigrantes da Fundação Casa de Rui Barbosa (CEPRI - Casa Rui). Trabalho como pesquisadora voluntária no Laboratório de Estudos de Mídia e Relações Internacionais (LEMRI/UFRJ). Trabalhei como pesquisadora no Laboratório de Estudos de Mídia e Esfera Pública (LEMEP/IESP-UERJ) no Projeto Manchetômetro / pesquisadora no Laboratório de Simulações e Cenários na Escola de Guerra Naval (EGN/LSC/MB) / pesquisadora voluntária do Laboratório de Segurança Internacional e Defesa Nacional na Escola Superior de Guerra (LABSDEN/ESG). E-mail: jessika_medeiross@ hotmail.com.

Recebido em: 05.10.2017

Aprovado em: 22.05.2019

Este artigo é publicado em acesso aberto (Open Access) sob a licença Creative Commons Attribution Non-Commercial (CC-BY-NC), que permite uso, distribuição e reprodução em qualquer meio, sem restrições, desde que sem fins comerciais e que o trabalho original seja corretamente citado.

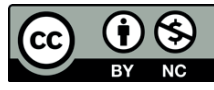

